\title{
Review article: the role of oxidative stress in pathogenesis and treatment of inflammatory bowel diseases
}

\author{
Aleksandra Piechota-Polanczyk • Jakub Fichna
}

Received: 22 November 2013 / Accepted: 24 April 2014 /Published online: 6 May 2014

(C) The Author(s) 2014. This article is published with open access at Springerlink.com

\begin{abstract}
In this review, we focus on the role of oxidative stress in the aetiology of inflammatory bowel diseases (IBD) and colitis-associated colorectal cancer and discuss free radicals and free radical-stimulated pathways as pharmacological targets for anti-IBD drugs. We also suggest novel antioxidative agents, which may become effective and less-toxic alternatives in IBD and colitis-associated colorectal cancer treatment. A Medline search was performed to identify relevant bibliography using search terms including: 'free radicals,' 'antioxidants,' 'oxidative stress,' 'colon cancer,' 'ulcerative colitis,' 'Crohn's disease,' 'inflammatory bowel disease.' Several therapeutics commonly used in IBD treatment, among which are immunosuppressants, corticosteroids and anti-TNF- $\alpha$ antibodies, could also affect the IBD progression by interfering with cellular oxidative stress and cytokine production. Experimental data shows that these drugs may effectively scavenge free radicals, increase anti-oxidative capacity of cells, influence multiple signalling pathways, e.g. MAPK and NF-kB, and inhibit pro-oxidative enzyme and cytokine concentration. However, their anti-oxidative and antiinflammatory effectiveness still needs further investigation. A highly specific antioxidative activity may be important for the clinical treatment and relapse of IBD. In the future, a combination of currently used pharmaceutics, together with natural and synthetic anti-oxidative compounds, like lipoic acid or curcumine, could be taken into account in the design of novel anti-IBD therapies.
\end{abstract}

Keywords Freeradicals · Crohn's disease - Ulcerative colitis · Antioxidants $\cdot$ Corticosteroids $\cdot$ Anti-TNF- $\alpha$ antibodies

\footnotetext{
A. Piechota-Polanczyk $\cdot$ J. Fichna $(\varangle)$

Department of Biochemistry, Faculty of Medicine, Medical

University of Lodz, Mazowiecka 6/8, 92-215 Lodz, Poland

e-mail: jfichna@hotmail.com
}

\section{List of non-standard abbreviations}

AGE

AP-1

ARE

CAT

CD

eNOS

GI

GRd

GSH

GSSG

GPx

$\mathrm{H}_{2} \mathrm{O}_{2}$

$\mathrm{HO}$

IBD

ICAM

IL

$\mathrm{IkB}$

IFN- $\gamma$

iNOS

LOX

MAPK

MPO

NF-kB

NOS

NOX

$\mathrm{NO}^{\circ}$

$\mathrm{ONOO}^{-}$

$\mathrm{O}_{2}$ '

$\mathrm{OCl}^{-}$

$\mathrm{OH}^{\bullet}$

PMNS

ROS

RNS

SOD1

SOD2
Advanced glycation end products

Activator protein 1

Antioxidant response element

Catalase

Crohn's disease

Endothelial nitric oxide synthase

Gastrointestinal

Glutathione reductase

Reduced glutathione

Oxidised glutathione

Glutathione peroxidase

Hydrogen peroxide

Heme oxygenase

Inflammatory bowel diseases

Intracellular adhesion molecule

Interleukin

Alpha- inhibitor of $\mathrm{kB}$ alpha of NF-kB

Interferon gamma

Inducible nitric oxide synthase

Lipooxygenase

Mitogen-activated protein kinases

Myeloperoxidase

Nuclear factor-kappa B

Nitric oxide synthase

NADPH oxidase

Nitric oxide

Peroxynitrate

Superoxide anion

Hypochlorite ion

Hydroxyl radical

Polymorphonuclear neutrophils

Reactive oxygen species

Reactive nitrogen species

Copper/zinc superoxide dismutase

Mitochondrial superoxide dismutase 


$\begin{array}{ll}\text { SOD3 } & \text { Extracellular superoxide dismutase } \\ \text { UC } & \text { Ulcerative colitis } \\ \text { TNF- } \alpha & \text { Tumour necrosis factor alpha } \\ \text { TNFR } & \text { Tumour necrosis factor receptor } \\ \text { XO } & \text { Xanthine oxidase }\end{array}$

\section{Introduction}

Cells are continuously threatened by the damage caused by reactive oxygen/nitrogen species (ROS/RNS), which are produced during physiological oxygen metabolism. Both ROS and RNS at low and moderate concentrations are signalling molecules involved in mitogenic response or in defence against infectious agents. However, excessive production of ROS and RNS or their inefficient scavenging leads to oxidative and nitrosative stress, respectively. This condition is potentially dangerous as it may alter inflammatory response and lead to lipid and protein modifications, DNA damage, apoptosis or cancerogenic cell transformation (Valko et al. 2001; Ridnour et al. 2005; Valko et al. 2007). Because of this, oxidative stress has been implicated in a number of human diseases, including inflammatory bowel diseases (IBD) and colorectal cancer.

This review will summarise the latest reports on the role of oxidative stress and oxidative stress-induced signalling pathways in the aetiology of ulcerative colitis (UC), Crohn's disease (CD) and colitis-associated colorectal cancer. We will also focus on the effects of well-established therapeutics on oxidative stress and suggest future strategies for the treatment of free radicals production in UC, CD and colitis-associated colorectal cancer.

\section{Types and sources of free radicals in intestinal tissue}

\section{Reactive oxygen species}

The most abundant free radical in human tissues is the superoxide anion $\left(\mathrm{O}_{2}{ }^{-}\right)$, generated by the addition of one electron to molecular oxygen (Miller et al. 1990). Its main source in a cell is complex I and III of the mitochondrial electron transport chain, which converts $1-3 \%$ of total oxygen to the superoxide anion (Muller et al. 2004) (Table 1 and Fig. 1 reaction (7)). Another source of $\mathrm{O}_{2}{ }^{-}$is an enzymatic reaction catalysed by xanthine oxidase (XO) [Fig. 1 reaction (1)] and membrane enzyme complexes named NADPH oxidases (NOX) (see Fig. 1). The NOX family comprises five isoforms, from which NOX1 is highly expressed in colon epithelium (Dutta and Rittinger 2010). When activated, NOX1 catalyses the transmembrane electron transport to two molecular oxygens forming $\mathrm{O}_{2}{ }^{-}$. NOX1-induced $\mathrm{O}_{2}{ }^{-}$at the luminal surface of the colon has been suggested to enhance host defence (Geiszt et al. 2003). Moreover, NOX1 and NOX4 have been implicated as persistent, endogenous ROS generators that may contribute to the hepatitis $\mathrm{C}$ virus-related pathologies (de Mochel et al. 2010).

Under stress conditions, $\mathrm{O}_{2}{ }^{--}$concentrations rise leading to excessive production of deleterious hydroxyl radical $\left(\mathrm{OH}^{*}\right)$ through the Haber-Weiss reaction. The hydroxyl radical is also generated from hydrogen peroxide $\left(\mathrm{H}_{2} \mathrm{O}_{2}\right)$ in the reaction catalysed by ferrous ion $\left(\mathrm{Fe}^{2+}\right)$ [the Fenton reaction; Fig. 1 reaction (3)]. Instead of ferrous, other transient metals like copper, chromium or cobalt may participate in $\mathrm{OH}^{*}$ generation, those reactions become a significant source of $\mathrm{OH}^{*}$ under oxidative stress conditions or when the concentration of free, unbounded transient ions increases, e.g. during hemodialysis. In the gastrointestinal (GI) tract, $\mathrm{OH}^{\bullet}$ inactivates a crucial mitochondrial enzyme pyruvate dehydrogenase, depolymerises GI mucin and inflicts mitochondrial RNA and DNA damages (Tabatabaie et al. 1996; Takeuchi et al. 1996; Halliwell 1999).

Another protonated form of $\mathrm{O}_{2}{ }^{-}$is perhydroxyl radical $\left(\mathrm{HOO}^{\circ}\right)$, which initiates fatty acid peroxidation. Lipid peroxidation disturbs integrity, fluidity and permeability of biomembranes, modifies lipoproteins to pro-inflammatory forms and generates potentially toxic products. Moreover, lipid peroxidation products have been shown to possess mutagenic and carcinogenic properties (Poli et al. 2008; Winczura et al. 2012).

Apart from mitochondria, another source of free radicals in cells is plasma membrane NADPH oxidases or peroxisomes, which consume oxygen and produce $\mathrm{H}_{2} \mathrm{O}_{2}$. Under physiological conditions, peroxisome-derived $\mathrm{H}_{2} \mathrm{O}_{2}$ is converted to water by catalase (CAT) [Fig. 1 reaction (4)]. However, damaged peroxisome releases $\mathrm{H}_{2} \mathrm{O}_{2}$ directly to cytoplasm, therefore contributing to oxidative stress. Moreover, together with $\mathrm{O}_{2}{ }^{-}, \mathrm{H}_{2} \mathrm{O}_{2}$ may be converted to highly toxic and oxidising $\mathrm{OH}^{\circ}$ hydrogen peroxide in Fenton and Haber-Weiss reactions (Fransen et al. 2012).

In the GI tract, $\mathrm{O}_{2}{ }^{--}$is mainly generated by $\mathrm{XO}$ [Fig. 1 reaction (1)]. It is consequently converted to $\mathrm{H}_{2} \mathrm{O}_{2}$ in the reaction catalysed by CAT and/or glutathione peroxidase (GPx) [Fig. 1 reaction (4) and (5), respectively]. $\mathrm{H}_{2} \mathrm{O}_{2}$ produced by neutrophils is subsequently utilised by myeloperoxidase (MPO) to produce hypochlorite ion $\left(\mathrm{OCl}^{-}\right)$. Superoxide anion is a highly reactive, highly unstable, very short lived form of ROS which causes it to react away very quickly and makes it membrane impermeable; therefore, it acts near the place of its origin causing oxidation of surrounding biomolecules, while $\mathrm{H}_{2} \mathrm{O}_{2}$ can freely diffuse across cell membranes and oxidise compounds located further, e.g. membrane lipids of pathogens. The $\mathrm{H}_{2} \mathrm{O}_{2}$ diffusion in GI is facilitated by aquaporin 8 (Te Velde et al. 2008). Interestingly, basal level of ROS in enterocytes differs, with lower 
Table 1 Enzymatic reactions that participate in ROS/NOS generation in the GI tract

\begin{tabular}{|c|c|c|c|}
\hline Enzyme & Reaction & Site of action & $\begin{array}{l}\text { Reaction } \\
\text { No. in } \\
\text { Fig. } 1\end{array}$ \\
\hline $\begin{array}{l}\text { complex I and III/ubiquinone of the } \\
\text { mitochondrial electron transport } \\
\text { chain }\end{array}$ & $\begin{array}{l}\text { Complex I (NADH dehydrogenase): } \\
\mathrm{O}_{2}+\mathrm{NADH} \rightarrow \mathrm{O}_{2}^{-{ }^{-}+\mathrm{NAD}^{+}} \\
\left.\text {Complex III (cytochrome bc }{ }_{1}\right) \\
\mathrm{O}_{2} \rightarrow \mathrm{O}_{2}^{--}\end{array}$ & Mitochondria & \\
\hline Xanthine oxidase & $\begin{array}{l}\text { Xanthine }+\mathrm{O}_{2}+\mathrm{NADPH} \\
\quad \mathrm{NADP}^{+}+\text {uric acid }\end{array}$ & Plasma and cytoplasm of epithelial cells & $(1)$ \\
\hline NADPH oxidase & $2 \mathrm{O}_{2}+\mathrm{NADPH} \rightarrow 2 \mathrm{O}_{2}{ }^{-}+\mathrm{NADP}^{+}+\mathrm{H}^{+}$ & Cell membrane & (2) \\
\hline Haber-Weiss reaction & $\mathrm{H}_{2} \mathrm{O}_{2}+\mathrm{O}_{2}^{\cdot-} \rightarrow \mathrm{O}_{2}+\mathrm{OH}+\mathrm{OH}^{\cdot}$ & Plasma and cell's cytoplasm & \\
\hline Fenton reaction & $\mathrm{H}_{2} \mathrm{O}_{2}+\mathrm{Fe}^{2+} \rightarrow \mathrm{Fe}^{3+}+\mathrm{OH}+\mathrm{OH}^{\cdot}$ & Plasma and cell's cytoplasm & (3) \\
\hline Catalase (CAT) & $2 \mathrm{H}_{2} \mathrm{O}_{2} \rightarrow \mathrm{O}_{2}+\mathrm{H}_{2} \mathrm{O}$ & $\begin{array}{l}\text { the cytoplasm and peroxisomes of epithelium } \\
\text { and lamina propria; leukocytes. }\end{array}$ & (4) \\
\hline Glutathione peroxidase (GPx) & $\mathrm{H}_{2} \mathrm{O}_{2}+2 \mathrm{GSH} \rightarrow \mathrm{GSSG}+2 \mathrm{H}_{2} \mathrm{O}$ & $\begin{array}{l}\text { GPx1- peroxisomes of colon lymphatic tissue } \\
\text { and the lamina propria, submucosa, } \\
\text { muscularis and serosa; } \\
\text { GPx2- peroxisomes of the luminal epithelium; } \\
\text { GPx3- secreted by the intestinal epithelial cells; } \\
\text { GPx4- peroxisomes of colonic and ileal tissues. }\end{array}$ & $(5)$ \\
\hline $\begin{array}{l}\text { Endothelial nitric oxide synthase } \\
\text { (eNOS) }\end{array}$ & $\mathrm{L}$-arginine $+\mathrm{O}_{2} \rightarrow$ L-citrulline $+\mathrm{NO}^{\bullet}$ & Cell membrane of the endothelial cells & (6) \\
\hline Inducible nitric oxide synthase (iNOS) & $\mathrm{NO}^{\cdot}+\mathrm{O}_{2}^{\cdot-} \rightarrow \mathrm{ONOO}^{-}$ & Cytoplasm of inflammatory and epithelial cells & \\
\hline Superoxide dismutase (SOD) & $2 \mathrm{H}^{+}+2 \mathrm{O}_{2}^{\cdot-} \rightarrow \mathrm{O}_{2}+\mathrm{H}_{2} \mathrm{O}_{2}$ & $\begin{array}{l}\text { SOD1- cytoplasm and small amount in nucleus; } \\
\text { SOD2- mitochondria; } \\
\text { SOD3- plasma. }\end{array}$ & (7) \\
\hline Glutathione reductase (GRd) & $\mathrm{GSSG}+\mathrm{NADPH} \rightarrow \mathrm{GSH}+\mathrm{NADP}^{+}$ & Like GPx & $(8)$ \\
\hline
\end{tabular}

concentration of ROS in small intestine and higher in colon (Sanders et al. 2004). The differences in ROS generation may influence the levels of oxidised proteins, lipids and DNA damage, thus contributing to the higher susceptibility of colon to GI diseases at these two intestinal sites.

During pathological states, circulating XO binds to vascular endothelial cells and produces site-specific oxidative injury of the intestine tissue (Tan et al. 1993). Moreover, activated neutrophils undergo series of reactions termed "the respiratory burst," in which $\mathrm{O}_{2}{ }^{--}$is generated. It was shown that this process incorporates NOX enzymes, especially NOX2, because NOX2 knockout mice have reduced oxidative burst and are less susceptible to experimentally induced ulcerative colitis (Bao et al. 2011).

\section{Reactive nitrogen species}

The second group of free radicals are reactive nitrogen species that are by-products of nitric oxide synthases (NOS), which are expressed in selected cells of the intestinal submucosa and mucosal regions. NOS metabolises arginine to citrulline and forms the nitric oxide radical $\left(\mathrm{NO}^{\circ}\right)$ via a five-electron oxidative reaction (Ghafourifar and Cadenas 2005). The nitric oxide radical has a relatively long half-life, but slow reaction time due to its rapid diffusion into the bloodstream and inactivation by haemoglobin. The nitric oxide radical is vital for proper functioning of an organism, as its physiological action includes neurotransmission, blood pressure regulation and immunomodulation. Furthermore, the vasodilatory actions of $\mathrm{NO}^{\circ}$ play a prominent role in the capillary recruitment of absorptive hyperaemia, catalysed by the endothelial NOS (eNOS) isoform, localised to the microvasculature at the submucosa-mucosa interface (Matheson et al. 2000). In addition, the nitric oxide radical protects epithelial cells against $\mathrm{H}_{2} \mathrm{O}_{2}$ induced toxicity and diminishes leukocyte adhesion to endothelial cells (Kim and Kim 1998; Binion et al. 2000). While eNOS produces $\mathrm{NO}^{\circ}$ in a pulsative way, the other NOS isoform termed inducible NOS (iNOS) produces $\mathrm{NO}^{\circ}$ in a constant manner. iNOS is detected only in inflamed tissue and is responsible for an excessive generation of RNS in activated macrophages, leukocytes and epithelial cells in the intestinal mucosa (Dijkstra et al. 1998). It was demonstrated that in UC, the activation of iNOS/cyclooxygenase-2 (COX2)/5-lipooxygenase (5-LOX) loop and increased contents of their end products, namely $\mathrm{NO}$, prostaglandin $\mathrm{E}_{2}\left(\mathrm{PGE}_{2}\right)$ and leukotriene $\mathrm{B}_{4}\left(\mathrm{LTB}_{4}\right)$, contribute to a damage of large intestine mucous membrane by overproduction of free radicals and impairment of anti-oxidative system (Sklyarov et al. 2011). Moreover, iNOS-derived NO reacts with tyrosine leading to nitrotyrosine production. It was indicated that patients with 


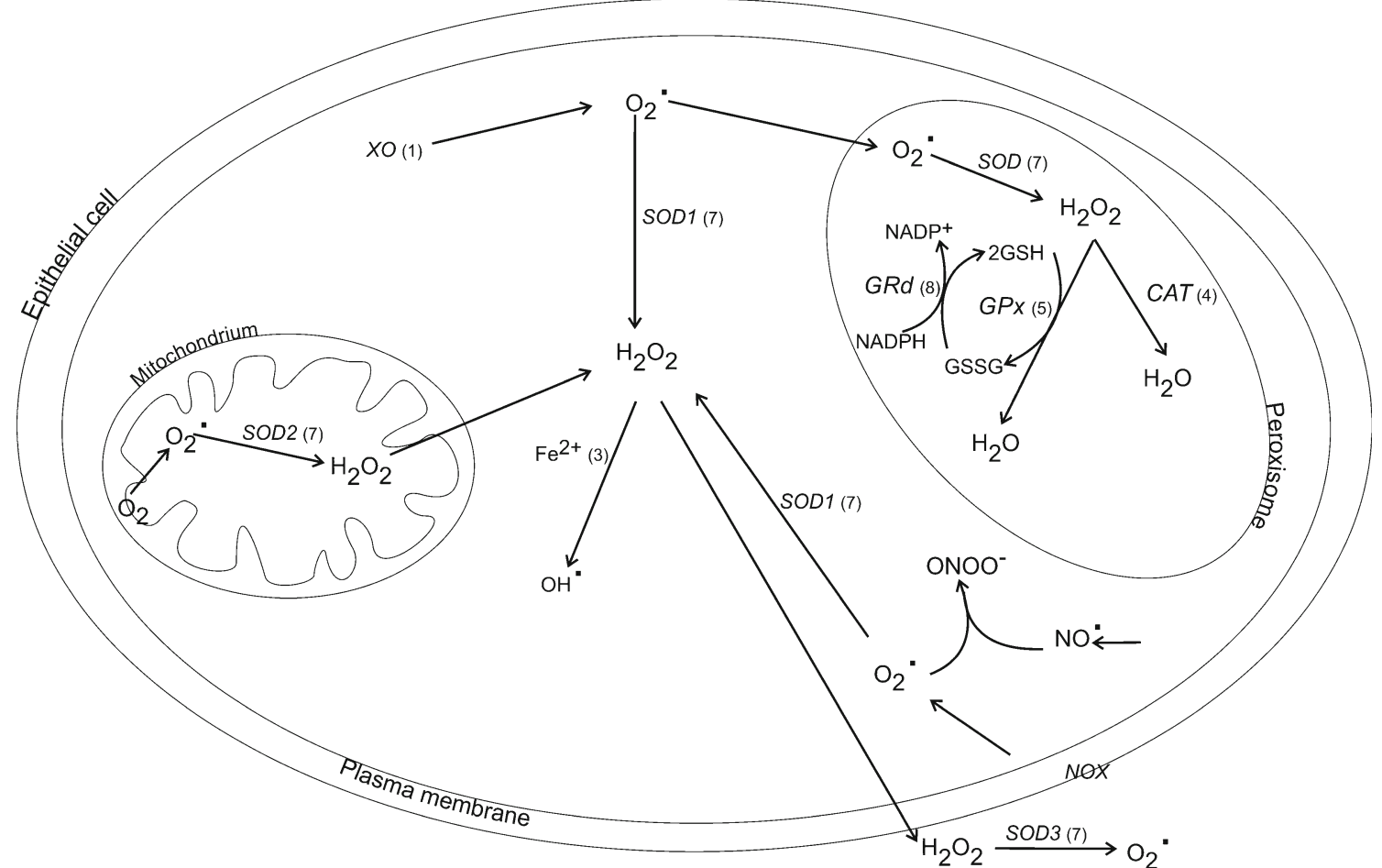

Fig. 1 Formation of ROS and anti-oxidant defence system in intestinal epithelial cells. CAT catalase, GRd glutathione reductase, GSH reduced glutathione, GSSG oxidised glutathione, GPx glutathione peroxidise, $\mathrm{H}_{2} \mathrm{O}_{2}$ hydrogen peroxide, $\mathrm{NO}^{*}$ nitric oxide, $\mathrm{NOX}$ NADPH oxidase, $\mathrm{ONOO}^{-}$peroxynitrate, $\mathrm{O}_{2}{ }^{-}$superoxide anion, $\mathrm{OH}^{\circ}$ hydroxyl radical,

UC, but not collagenous colitis, have intense epithelial staining for nitrotyrosine associated with infiltration of neutrophils in the epithelium (Perner et al. 2001).

The reaction between $\mathrm{NO}^{\circ}$ with $\mathrm{O}_{2}{ }^{--}$leads to peroxynitrite production $\left(\mathrm{ONOO}^{-}\right)$, which is an aggressive oxidising agent that can cause DNA fragmentation and lipid oxidation. Peroxynitrite is generated in cells containing NOS enzymes, such as smooth muscle or endothelial cells and, in particular during inflammatory response, by stimulated leukocytes.

\section{Lipid peroxidation and lipid radicals}

Both ROS and RNS can contribute to lipid peroxidation. Particularly susceptible to oxidative damages are membrane lipids and lipoproteins since they are rich in polyunsaturated fatty acids. During lipid peroxidation, a hydroperoxy group is introduced into the hydrophobic tails of unsaturated fatty acids. This change can result in structural alterations of biomembranes and lipoproteins via disturbance of hydrophobic lipid-lipid and lipidprotein interactions, or can lead to generation of hydroperoxyl radicals and reactive aldehyde derivates, which may induce secondary modifications of other cell
$S O D 1$ cooper/zinc superoxide dismutase, $S O D 2$ mitochondrial superoxide dismutase, SOD3 extracellular superoxide dismutase, $X O$ xanthine oxidase. Numbers corresponds to reactions catalysed by representative enzymes and presented in Table 2

components. The end products of lipid peroxidation, like malondialdehyde or 4-hydroxynonenal, can cause protein damage by reactions with lysine amino groups, histidine imidazole groups or cysteine sulphydryl groups [see review (Catala 2009)].

Lipid radicals originate as well from LOX enzymes that catalyse dioxygenation of polyenoic fatty acids forming hydroperoxides. In the intestines, a substantial role is played by 5-LOXs, as it catalyses the oxidation of arachidonic acid. The hydroperoxides that are generated by LOX enzymes are then reduced by GPx [see review (Kuhn and Borchert 2002)].

Patients with $C D$, especially during an active phase of the disease, have higher plasma levels of lipid peroxidation products, as well as a decreased peroxidation potential and oxidative LDL level (Boehm et al. 2012). Although lipid peroxidation occurs in IBD patients, it may have different origin depending on the IBD type. Kruidenier et al. (2003) showed that in CD, lipid peroxidation is associated with mitochondrial superoxide dismutase (SOD) activity, suggesting the involvement of $\mathrm{OH}^{*}$ and $\mathrm{O}_{2}{ }^{--}$, while the amount of lipid peroxidation products is associated with epithelial CAT expression and neutrophilic MPO activity in UC, suggesting a $\mathrm{H}_{2} \mathrm{O}_{2}$ - and/or $\mathrm{OCl}^{-}$-mediated mechanism. 


\section{Anti-oxidative mechanisms in GI tract}

A non-harmful concentration of ROS/RNS is sustained by the anti-oxidative defence mechanisms, that include enzymes such as CAT, SOD or GPx and non-enzymatic endo- and exogenous scavengers like glutathione (GSH), transient ions (e.g. $\mathrm{Fe}^{2+}, \mathrm{Cu}^{2+}$ ) or flavonoids (Fig. 1). Noteworthy, it was demonstrated that the colonic enterocytes are characterised not only by higher ROS contents, as mentioned earlier, but also by higher concentration of CAT, SOD and GPx compared to small intestine tissue (Sanders et al. 2004).

Three mammalian SOD isoforms, copper/zinc (SOD1), mitochondrial (SOD2) and extracellular (SOD3), catalyse the reaction of $\mathrm{O}_{2}{ }^{--}$reduction to $\mathrm{H}_{2} \mathrm{O}_{2}$ (Fridovich 1997) [Fig. 1 reaction (7)]. SOD1 is a cyanide-sensitive homodimer localised mainly in the cytoplasm and to some extent in the nucleus, but absent in the mitochondria of epithelial cells and phagocytes (Pietarinen-Runtti et al. 2000; Kruidenier and Verspaget 2002). The mitochondria are protected from $\mathrm{O}_{2}{ }^{-}$ by SOD2, which is vital for cell survival as mice lacking SOD2 gene die within several days after birth (Li et al. 1995). SOD3 dominates in plasma and interstitium (Kruidenier and Verspaget 2002) and has a high affinity to glycosaminoglycans like heparin (Marklund 1982).

Approximately $70 \%$ of total SOD is expressed as SOD1, which not only dismutes $\mathrm{O}_{2}{ }^{-}$, but can also convert $\mathrm{H}_{2} \mathrm{O}_{2}$ in the presence of copper ion, forming $\mathrm{OH}^{*}$ or peroxynitrate (Ischiropoulos and al-Mehdi AB 1995). SOD-produced $\mathrm{H}_{2} \mathrm{O}_{2}$ is converted to water in the reaction catalysed by CAT or GPx. CAT is widely expressed in the cytoplasm and peroxisomes of colonic epithelium and lamina propria and activated when concentrations of $\mathrm{H}_{2} \mathrm{O}_{2}$ increase, e.g. during inflammatory process. In contrast, $\mathrm{H}_{2} \mathrm{O}_{2}$ produced during normal cell metabolism is reduced by GPx in the presence of NADPH. GPx has higher affinity to $\mathrm{H}_{2} \mathrm{O}_{2}$ than CAT and also reduces lipid hydroperoxide levels, preventing peroxynitrite-mediated oxidation (Sies et al. 1997).

Currently, there are five isoforms of GPx, which belong to the group of selenium-dependent enzymes. GPx1 and GPx2 play an important role in the intracellular antioxidant defence, but in different layers of the gut; GPx1 is highly expressed in the colon lymphatic tissue and the lamina propria, submucosa, muscularis and serosa, but not the luminal epithelium, which is the area of the action of GPx2. GPx3 most likely contributes to the extracellular antioxidant defence of the intestinal mucosa, as it is secreted by intestinal epithelial cells (Esworthy et al. 1998; Tham et al. 1998). Recently, GPx4 has been detected in colonic and ileal tissues (Florian et al. 2010). This isoform is responsible for a repair of oxidatively damaged DNA by reducing thymine hydroperoxide and for scavenging phospholipid hydroperoxides and repressing lipid peroxidation (Bao et al. 1997; Seiler et al. 2008).
GPx enzymatic activity requires glutathione as a proton donor. GSH is a water-soluble tripeptide composed of the amino acids glutamine, cysteine and glycine, containing the cysteine-derived thiol group, which is a potent reducing agent. GSH is highly abundant in the cytoplasm $(1-11 \mathrm{mM})$, nucleus $(3-15 \mathrm{mM})$ and mitochondria $(5-11 \mathrm{mM})$ and is the major soluble antioxidant in these cell compartments. GSH homeostasis in healthy tissues is sustained by de novo synthesis from cysteine, the regeneration of oxidised glutathione (GSSG), as well as from GSH uptake via sodium-dependent transport systems (Aw 2005). The reduction of two GSH particles in the presence of NADPH leads to the synthesis of GSSG. GSH is next regenerated from GSSG in the reaction mediated by GSH reductase (GRd) [Fig. 1 reactions (5) and (8)] or it is eliminated from the cell via export into the extracellular space (Bachhawat et al. 2013).

Several reports showed that the sufficient concentration of GSH in the jejunal and colonic epithelial cells prevents tissue degradation by eliminating harmful peroxides (Aw 2005), while the loss of GSH/GSSG redox balance contributes to tissue hyperplasia, mucosal inflammation and clinical symptoms of colitis (Tsunada et al. 2003). Oxidants like $\mathrm{H}_{2} \mathrm{O}_{2}$ were also shown to stimulate cysteine uptake and GSH synthesis (King et al. 2011). Furthermore, the promoter region of $\gamma$ glutamylcysteine synthetase, an enzyme involved in GSH synthesis, contains ROS-sensitive activator protein 1 (AP-1) binding site and an antioxidant response element (ARE) (Rahman et al. 1998). When activated, those regions increase GSH synthesis, thus enhancing anti-oxidative abilities of the cell (Aw 2005).

\section{Targeting oxidative stress in IBD}

\section{Ulcerative colitis}

ROS and NOS, as well as pro-inflammatory cytokines have a long-standing implication in both the aetiology and the progression of UC (Seril et al. 2003). A significant infiltration by neutrophils and increase in MPO levels was observed in the inflamed lamina propria of humans with UC in close approximation to the epithelia (Kruidenier et al. 2003). It was also shown in mice that the onset and severity of colitis were significantly attenuated by iNOS gene ablation (Krieglstein et al. 2001). In UC, iNOS is considered to be responsible for greatly increased production of $\mathrm{NO}$ in the epithelium and in foci of inflammation in association with nitrotyrosine (Singer et al. 1996). iNOS-derived NO stimulates TNF- $\alpha$ production in the middle and distal colon, which promotes the infiltration of neutrophils for example through stimulation of synthesis of intracellular adhesion molecule (ICAM) and P-selectin, therefore leading to colonic tissue damage (Yasukawa et al. 2012). Neutrophil recruitment and activation of key transcriptional 
signalling pathways like nuclear factor-kappa B (NF-kB) and AP-1 augment the inflammatory response and tissue damage (Brennan et al. 1995). When activated, NF-kB translocates to the nucleus, binds DNA and subsequently activates gene expression. The activated genes involved in mucosal inflammation include cytokines IL-6, IL-8 IL-1 $\beta$, IL-10, TNF- $\alpha$ and ICAM (Yasukawa et al. 2012). Recently, Gan et al. (2005), documented an increased activation of NF-kB and high levels of the expression of interleukin IL-1 $\beta$ mRNA and IL-8 mRNA in human UC tissue.

Although UC is a well-known inflammatory bowel disease, the search for reliable disease markers continues. Studies reported higher concentration of serpin $\mathrm{B} 1$, a neutrophil elastase inhibitor which reduces $\mathrm{H}_{2} \mathrm{O}_{2}$-induced tissue damage in patients with inflamed UC (Uchiyama et al. 2012). Furthermore, those patients were more likely to possess a polymorphism in the CAT promoter region (C-262T) that alters CAT expression levels (Khodayari et al. 2013). Moreover, the proteomic characterization of inflamed colonic tissue demonstrated a relatively higher level of oxidative stress-response proteins like selenium binding protein, SOD and thioredoxindependant peroxide reductase, as well as higher expression of proteins implicated in energy generation like isocitrate dehydrogenase, L-lactate dehydrogenase B-chain, inorganic pyrophosphatase or enoyl-CoA hydratase, which could indicate inflammation-associated alterations in energy metabolism (Poulsen et al. 2012).

Clinical studies indicated that combined treatment of UC patients with oral mesalamine $(2.4 \mathrm{~g} /$ day $)$ plus N-acetyl-Lcysteine $(0.8 \mathrm{~g} /$ day $)$ for 4 weeks showed better clinical responses (66 vs $50 \%$ in mesalamine alone group) accompanied by decreased levels of IL-8 and MCP-1 (Guijarro et al. 2008).

\section{Crohn's disease}

$\mathrm{CD}$ is characterised by reduced number of naive $\mathrm{T}$ cells and increased content of memory $\mathrm{T}$ cells, as well as higher expression of major histocompatibility complex (MHC) class II molecules in the colonocytes and in ileal epithelial cells (Ebert et al. 2005). At an early stage, patchy necrosis of the surface epithelium, focal accumulations of leukocytes adjacent to crypts and an increased number of intraepithelial macrophages and granulocytes are detected. Stimulated inflammatory cells produce ROS and RNS, but the mechanisms of free radical production and their sources in $\mathrm{CD}$ patients are complex. Previously, it was shown that blood polymorphonuclear neutrophils (PMNS) of patients with untreated CD have impaired infiltration ability, reduced SOD content, lower $\mathrm{O}_{2}{ }^{--}$ production and therefore, decreased $\mathrm{H}_{2} \mathrm{O}_{2}$ generation (Verspaget et al. 1984; Verspaget et al. 1988; Curran et al. 1991). This is in line with Maor et al. (2008), who documented reduced release of $\mathrm{O}_{2}{ }^{--}$and lysozyme from neutrophils of patients with active but not stable $\mathrm{CD}$. The authors speculated however, that the decreased superoxide anion production by the isolated PMNS might be caused by improper separation technique or the fact that the circulating substances present in serum exhausted their capacity for superoxide anion generation. Nevertheless, a positive correlation between the free radicals formation and pro-inflammatory cytokines content was described despite the fact that patients with active and stable $\mathrm{CD}$ had the anti-inflammatory medications in their clinical history (Maor et al. 2008). However, recent studies suggested that immune peripheral cells in patients with active CD have higher SOD activity and $\mathrm{H}_{2} \mathrm{O}_{2}$ production, increased lipid peroxidation, inhibited mitochondrial function and decreased CAT activity; interestingly those changes, apart from CAT activity, were reversed during disease remission showing an important role of mitochondria and oxidative stress in $\mathrm{CD}$ development (Beltran et al. 2010).

Also CD patients have higher $\mathrm{ONOO}^{-}$content, a byproduct of iNOS that is highly expressed in activated macrophages and neutrophils of colonic mucosa (Rachmilewitz et al. 1995).

The pathogenesis of CD may be as well associated with a decreased production of cytokines that suppress macrophage and $\mathrm{T}$ cell functions. For instance, intestinal tissue of $\mathrm{CD}$ patients is characterised by lower IL-4 mRNA expression, a cytokine, which delays $\mathrm{O}_{2}^{--}$production in PMNS (Nielsen et al. 1996). Moreover, CD patients have lower content of anti-oxidative compounds, including tissue GSH, which participates in GPx-catalysed $\mathrm{H}_{2} \mathrm{O}_{2}$ reduction, as well as plasma ascorbic acid, $\alpha$ - and $\beta$-carotene, lycopene and $\beta$ cryptoxanthin (Miralles-Barrachina et al. 1999; Wendland et al. 2001; Maor et al. 2008). However, serum content of anti-oxidative enzymes like GPx seems to depend on the CD state; during CD remission, GPx activity is stable or lower, while its activity rises in active CD (Tuzun et al. 2002; Maor et al. 2008). The mouse models of UC and CD showed that an up-regulation of gene expression of GPx2 and downregulation of aquaporin 8 (the facilitator of $\mathrm{H}_{2} \mathrm{O}_{2}$ diffusion) in the colon may play a protective role in defending against severe oxidative stress during IBD (Te Velde et al. 2008).

Apart from IL-4, several other cytokines play a role in CD, including TNF- $\alpha$, IL-1 $\beta$, IL-6 and IL-8 (Podolsky 2002). The release of cytokines is not only induced by ROS, but also by RNS. Recent study of (Rafa et al. 2013) showed an upregulated NOS mRNA expression in peripheral blood mononuclear cells and colonic mucosa in patients with active $\mathrm{CD}$ and suggested a positive correlation between NOS-derived $\mathrm{NO}^{\circ}$ and IL-6, IL-17A and IL-23 plasma levels.

The above-mentioned cytokines mediate their action via NF-kB and mitogen-activated protein kinase (MAPK) signalling pathways, and aberrant activation of NF-kB is involved in the pathogenesis of IBD (Schreiber et al. 1998). The participation of NF-kB and MAPK signalling pathways was presented in Fig. 2. Free radicals like superoxide anion are 
Fig. 2 The influence of ROS and cytokines on signalling pathways in intestinal epithelial cells. $A G E$ advanced glycation end products, $A P-1$ activator protein $1, I C A M$ intracellular adhesion molecule, $I L-6$ interleukin 6, IL-6R interleukin 6 receptor, $i N O S$ inducible nitric oxide synthase, $N F-k B$ nuclear factor-kappa B, $N O X$ NADPH oxidase, $M A P K$ mitogen-activated protein kinases, $O C l$ hypochlorite ion, $S O D 3$ extracellular superoxide dismutase, $T N F-\alpha$ tumour necrosis factor alpha, TNFR tumour necrosis factor receptor

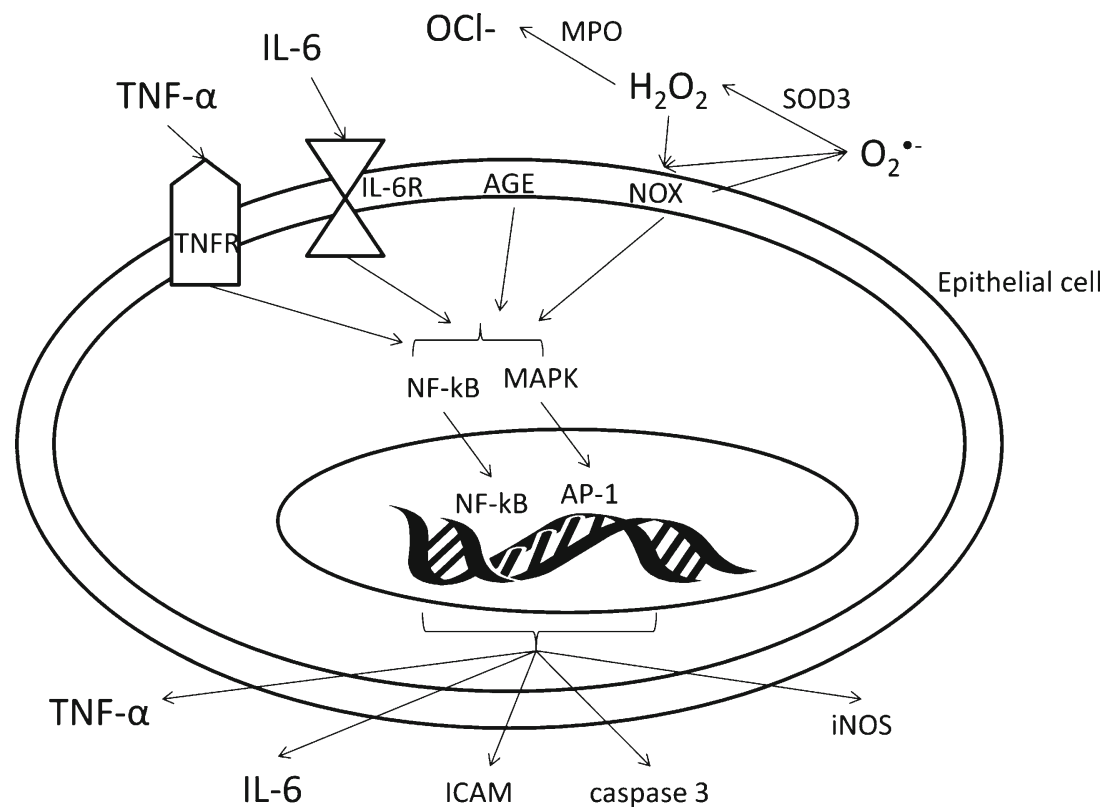

produced by NOX enzymes. The superoxide anion is converted to hydrogen peroxide by SOD3 and/or directly increases advanced glycation end products (AGE) content in plasma membrane of epithelial cells (Fig. 2). Both AGE and NOX, as well as pro-inflammatory cytokines e.g. IL-6 or TNF- $\alpha$ activate NF-kB signalling pathway leading to increased expression of caspase 3, ICAM, TNF- $\alpha$ or IL- 6 genes, while activation of MAPK results in ameliorated AP-1 signalling molecule expression and increased production of iNOS, the uninhibited source of NO. Taken together, the inhibition of NF-kB or p38 MAPK may decrease cytokine production in $\mathrm{CD}$ and influence ROS/RNS production in CD patients, especially during the active phase of the disease (Waetzig et al. 2002).

\section{Colitis-associated colorectal cancer-ROS/RNS contribution}

Carcinogenesis is generally a slow process and often takes decades from tumour initiation to diagnosis. The mutation and transformation process of a normal into a cancer cell can be triggered by accumulation of free radicals at the early stages and result in cancer progression. This might lead to an oxidative cellular damage or to an alteration in signalling pathways since ROS may act as signalling molecules.

Colorectal cancer remains the third most common cancer in both women and men worldwide (Chawla et al. 2013). It was demonstrated that during exogenous stress, the colon exhibits significantly greater oxidative DNA damage compared to the small intestine (Sanders et al. 2004). The oxidative environment results from excessive production of $\mathrm{O}_{2}{ }^{--}$in mitochondria, which can lead to the formation of other damaging agents like $\mathrm{H}_{2} \mathrm{O}_{2}$ and $\mathrm{OH}^{*}$. Moreover, it has been shown that mitochondrial respiration in the colon is less efficient than in other parts of intestines as the oxidation of butyrate, the primary energy substrate for colonocytes, yields $4.4 \mathrm{ATP} / \mathrm{O}_{2}$, while the oxidation of glutamine, the primary energy substrate for enterocytes, delivers 5.3 ATP/O $\mathrm{O}_{2}$ (Wu et al. 1995).

Apart from influencing mitochondrial metabolism, ROS modifies cell cycle. It was indicated that in human colon adenocarcinoma cells ROS stimulate expression of $\mathrm{p} 53$, which - among other functions - plays a role of an oxidative response transcription factor, therefore causing $\mathrm{S}$ phase arrest (Sun et al. 2012).

The association between inflammation and cancer involves key inflammatory mediators, such as NF-kB-targeted gene products including $\mathrm{TNF} \alpha$, and COX-2. It was observed that down-regulation of COX-2 accelerated tissue healing in experimental colitis (Zwolinska-Wcislo et al. 2011) and the inhibition of COX-2 enzyme by therapeutic agents to prevent damage by ROS was thus proposed as a strategy for cancer chemoprevention. Other chemoprotective targets include the Kelch-like ECH-associated protein 1 (Keap1) and its binding protein, transcription factor NF-E2-related factor-2 (Nrf2), because of their role in regulating the antioxidant response element in response to oxidative stress (Chang et al. 2013). $\mathrm{Nrf} 2$ regulates the expression of anti-inflammatory enzymes like XO-1 and GSH transferase (Schuhmacher et al. 2011). Recently, it was indicated that Nrf2 deficiency in epithelial cells leads to oxidative stress and DNA lesions, accompanied by impairment of cell cycle progression, mainly G2/M-phase arrest (Reddy et al. 2008). This effect is decreased after addition of the redox status regulator, GSH, which is known to act as a growth regulator, whereas GSH deficiency results in growth arrest (Iwata et al. 1997). Additionally, Nrf2-mediated and ROS-dependant cell cycle arrest is accompanied by HO-1 
expression, followed by $\mathrm{p} 21$ induction and prevention of neointimal hyperplasia (Kim et al. 2009).

Another strategy for cancer chemoprevention is to induce apoptosis via activation of MAPK pathways, in particular those involving c-Jun N-terminal kinase 1 (JNK) and p38 (Davis 2000; Ono and Han 2000). It was recently reported that mice with epithelial-deleted p38-MAPK in the colon had greater tumour development mediated by impaired cell cycle regulation (Wakeman et al. 2012). Also the GSH transferase, an enzyme incorporated in GSH metabolism, was shown to form protein-protein interactions with members of the MAPK pathway, thereby serving a regulatory role in the balance between cell survival and apoptosis (Scharlau et al. 2009).

The involvement of oxidative stress-regulated pathways in colon carcinoma was also confirmed in the in vitro experiments with free radical scavengers. For instance, the group of Hsu et al. (2007) showed that the administration of Nacetylocysteine (NAC), a ROS scavenger, reduced colonic cancer cell apoptosis via inhibition of JNK, p38 MAPK and activation of c-jun. Also, a pharmacological inhibition of ERK and 38 MAPK may decrease HO-1 up-regulation in colonic cells (Park et al. 2010). The induction of HO-1 gene expression is an important event in cellular response to pro-oxidative and pro-inflammatory compounds. However, further studies are necessary to determine the role of oxidative stress and oxidative stress-stimulated signalling pathways in colitisassociated colorectal cancer.

\section{Clinical view of the anti-oxidative role of drugs used in IBD treatment and their influence on IBD outcome}

Current treatment strategies for moderate-severe IBD consist immunosuppressants, corticosteroids and anti-TNF- $\alpha$ antibodies. Therapeutic effect of those drugs is in part contributed to their anti-inflammatory and anti-oxidative properties. Immunosuppressants and corticosteroids possess direct free radical-scavenging abilities while anti-TNF- $\alpha$ antibodies decrease TNF- $\alpha$ concentration having indirect anti-oxidative effect.

\section{Sulfasalazine and mesalazine}

Sulfasalazine is a potent cysteine transporter inhibitor composed of 5-aminosalicylic acid and sulfapyridine that has been routinely used in the clinical therapy of IBD (Gan et al. 2005). After oral intake, sulfasalazine is split by intestinal flora into sulfapyridine and mesalazine (Rijk et al. 1988). Like salicylates, the anti-inflammatory potential of sulfasalazine may be reflected by its influence on the release of adenosine, which controls oxidative potential, and by the effect of sulfasalazine on pro-inflammatory compounds content and free radicals generation. It was indicated that in clinical studies, a 6-week treatment with sulfasalazine to patients with mildly and moderately active UC resulted in a significant decrease of gut inflammation (Chen et al. 2005). This effect can be explained by sulfasalazine influence on ROS and pro-inflammatory cytokines content. It was shown that sulfasalazine decreased ROS concentration (Guo et al. 2011). In patients with moderate UC treated with sulfasalazine (2-4 g/day) for 8-36 weeks, a down-regulated activity of NF-kB accompanied by decreased expression of pro-inflammatory IL- $1 \beta$ mRNA and IL-8 mRNA was observed (Gan et al. 2005). When stimulated, NF-kB signalling pathway activates genes for e.g. proinflammatory cytokines production. Therefore, the downregulation of NF-kB activity under sulfasalazine treatment is desired. Interestingly, in patients with moderate UC, decreased concentration of NF-kB was independent of $\mathrm{IkB} \alpha$ level, which is a regulatory protein that inhibits NF-kB by trapping it in the cytoplasm (Gan et al. 2005). In response to a stimulus, $\mathrm{IkB} \alpha$ degrades and rapidly returns to the original level, what traps NF-kB and keeps it inactive, therefore indirectly inhibiting NF-kB effects (Scherer et al. 1995).

Deactivation of NF-kB by sulfasalazine was also described in the in vitro models. For instance, sulfasalazine-mediated inhibition of NF-kB induced apoptosis of T lymphocytes (Liptay et al. 1999) and macrophages (Brindley et al. 1996). In the macrophages, sulfasalazine also stimulates phospholipase $\mathrm{D}$, an enzyme involved in the regulation of cell signalling and oxidant stress, and the generation of phosphatidate (Brindley et al. 1996).

Sulfasalazine was also shown to inhibit extracellular release of pro-inflammatory secretory phospholipase A2 (Pruzanski et al. 1997).

Mesalazine (5-ASA), a metabolite of sulfasalazine, is widely used for the treatment of UC. At the cellular level 5-ASA reduces oxidative stress by inhibiting $\mathrm{O}_{2}{ }^{-}$and $\mathrm{H}_{2} \mathrm{O}_{2}$ production, as well as preventing mucosal GAPDH inhibition (Kimura et al. 1998; Campregher et al. 2010). Clinical trials indicated that in patients with UC, 4-week treatment with 5ASA ( $2.4 \mathrm{~g} /$ day) plus N-acetyl-L-cysteine $(0.8 \mathrm{~g} /$ day $)$ not only improved clinical response but also correlated with decreased blood TNF- $\alpha$, IL-6 and IL-8 concentration, as well as improved GSH content (Guijarro et al. 2008). 5-ASA administrated alone also improved clinical outcome, but with little effect on IL-6 and IL-8 content and with no influence on GSH and TNF- $\alpha$ concentration (Guijarro et al. 2008). Also in patients after ileocolonic resection of $\mathrm{CD}$, a 6-month 5-ASA (6 g/day) prevented the $\mathrm{CD}$ recurrence, but it did not reduce pro-inflammatory cytokine content; the concentration of mucosal TNF- $\alpha$, IL-1 $\beta$ and IL- 6 was increased (Yamamoto et al. 2009).

The possible difference in action between sulfasalazine and mesalazine in patients with IBD was recently described in a retrospective cohort study (Masuda et al. 2012). The authors observed that mesalazine group $(n=303,250-40,00 \mathrm{mg} /$ day 
for 111 days) had greater haematological adverse effects, expressed by lower white blood cells and platelet counts and higher mean serum urea nitrogen level than the sulfasalazine group ( $n=67,250-6,000 \mathrm{mg} /$ day for 116 days). Therefore, we may speculate that the haematological changes after 5-ASA therapy may influence free radical generation and proinflammatory cytokine content in IBD patients.

It should be also noticed that 5-ASA potently inhibits peroxynitrite-mediated DNA strand breakage, scavenges peroxynitrite and affects peroxynitrite-mediated radical formation responsible in part for 5-ASA anti-inflammatory and anti-cancer effects (Graham et al. 2013).

As discussed above, it may be suggested that sulfasalazine seems to be more effective than mesalazine. However, additional studies are necessary to evaluate the efficacy of sulfasalazine and 5-ASA in oxidative stress.

\section{Corticosteroids}

Systemic corticosteroids are highly effective at inducing clinical remission of UC and CD. Currently, a second generation of corticosteroids, which includes budesonide, prednisone or beclomethasone dipropionate, is in clinical use and they seem to possess fewer side effects in patients treated for UC and CD. Studies indicated that glucocorticoid therapy effectively inhibited neutrophil activity, reflected by decreased MPO and neutrophil elastase serum contents in paediatric IBD (Makitalo et al. 2012).

The anti-oxidative and anti-inflammatory action of glucocorticoids can be explained by their influence on NF-kB. It was demonstrated that glucocorticosteroids (e.g. prednisolone $0.75 \mathrm{mg} / \mathrm{kg} /$ day for 3 weeks) strongly inhibit intestinal NF-kB activation by stabilising the cytosolic $\mathrm{IkB} \alpha$ activation in tissue from patients with colitis (Ardite et al. 1998; Schreiber et al. 1998). Although helpful in decreasing ROS, corticosteroids do not seem to reduce the mucosal expression of NOS in patients with UC (Leonard et al. 1998). However, a recent study demonstrated a significant inhibition of NOS mucosal level and rectal NO production in patients with UC $(n=22)$ and $\mathrm{CD}(n=24)$ treated with prednisolone $(0.5-1 \mathrm{mg} / \mathrm{kg}$ orally for 1 month) (Ljung et al. 2006). Therefore, the effect of glucocorticosteroids on NOS and NO synthesis has to be further analysed.

It should also be stressed that corticosteroids may have a different effect on signalling pathways activity in CD patients who are steroid sensitive or steroid insensitive. Glucocorticoid treatment to steroid-sensitive patients lead to an activation of NF-kB, AP-1 and p38 MAPK mainly in lamina propria macrophages, while glucocorticoids mediated those changes mostly in epithelial cells in steroid-resistant patients (Bantel et al. 2002). Thus, steroid resistance is associated with increased epithelial activation of the above-mentioned pathways that may inhibit the anti-inflammatory glucocorticoid-induced action and accelerate disease progress.

\section{Cyclosporine}

Cyclosporine A, a calcineurine inhibitor, is an immunosuppressive drug which was shown to suppress the production of IL-2 and IL-3, inhibit chemotaxis of neutrophils and induce apoptosis in T cells of patients with UC (Ina et al. 2002; Kountouras et al. 2004). Cyclosporine A also decreased the number of neutrophils and mononuclear cells in colonic tissue and inhibited cytotoxic activity of $\mathrm{T}$ cells and mucosal chemokine activity in humans (Ina et al. 2002). When administered to humans, cyclosporine A binds to cyclophilin A, whose gene expression was shown to be up-regulated in the crypt epithelia of UC patients (Kim et al. 2006). The cyclosporine-cyclophilin A complex decreases TNF- $\alpha$ and IL-6 concentration by inhibiting the activity of NF-kB and MAPK signalling pathways in monocytes, therefore altering inflammatory processes (Yuan et al. 2010). However, no association was found between clinical response and whole blood cyclosporine A concentration in patients receiving both high ( $>5 \mathrm{mg} / \mathrm{kg} /$ day) and low ( $<5 \mathrm{mg} / \mathrm{kg} /$ day) oral cyclosporine A dose (Egan et al. 1998).

\section{Anti-TNF- $\alpha$ antibodies}

Infliximab is a monoclonal antibody against serum and membrane-bound TNF- $\alpha$, which decreases TNF- $\alpha$ concentration in colonic mucosa in patients with UC (Hart and $\mathrm{Ng}$ 2010). Infliximab treatment has been shown to decrease inflammation which improved mucosal healing in patients with UC via healing of the goblet cells and reducing abnormal mucus formation and secretion, which finally led to the recovery of the villi components (Fratila and Craciun 2010). Studies on 32 patients suffering from UC for about 4 years and treated with infliximab in repeated intravenous infusions at 0 , 2 and 6 weeks expressed lower mRNA of TNF- $\alpha$ and INF- $\gamma$ (Olsen et al. 2009). Moreover, UC remission was observed in eight patients after infliximab treatment. The colon tissue of UC remission patients was characterised by lower number of macrophages and lymphocytes; however, the level of TNF- $\alpha$ positive cells was unchanged (Olsen et al. 2009). Those changes can be attributed to inhibition of TNF- $\alpha$ generation and modulation of TNF- $\alpha$ stimulated signalling pathway. Apart from reducing mRNA for TNF- $\alpha$, infliximab decreased $\mathrm{T}$ lymphocyte and macrophage content and down-regulated the expression of IFN- $\gamma$ without affecting IL-10 and IL-4 mRNA (Olsen et al. 2009). Infliximab introduced to patients at a dose of $5 \mathrm{mg} /$ day for 2-4 weeks inhibited neutrophil activity, reflected by lower neutrophil elastase level, but not as efficiently as glucocorticoids at a dose of $0.8 \mathrm{mg} / \mathrm{kg} /$ day (Makitalo et al. 2012). Moreover, infliximab therapy 
decreased the up-regulation of leukocyte cell adhesion molecules and the inflammatory cell number in colonic lamina propria (Arijs et al. 2011). Furthermore, semi-chronic administration of anti-TNF- $\alpha$ antibodies increased blood contents of regulatory $\mathrm{T}$ cells and their suppressive function (Boschetti et al. 2011).

Unlike UC, CD is characterised by increased mucosal concentrations of TNF- $\alpha$ even during disease remission (Raddatz et al. 2005). Infliximab treatment lead to lower global numbers of CD4+ and CD8+ T lymphocytes and CD68, a marker of monocytes/macrophages (Baert et al. 1999). It also decreased mucosal expression of $T$ regulatory cells, counted as forked box P3 (FoxP3) level (Li et al. 2010). Therefore, targeting TNF- $\alpha$ generation in CD patients seems to be crucial. It was presented that infliximab treatment $(5 \mathrm{mg} /$ $\mathrm{kg}$, every 8 weeks for 6 months) to patients after resection of CD showed a decrease in mucosal IL- $1 \beta$, IL- 6 and TNF- $\alpha$ which contributed to the suppressive effect on clinical and endoscopic disease activity (Yamamoto et al. 2009). Similarly, six injections of adalimumab to $70 \mathrm{CD}$ patients $(80 \mathrm{mg}$ at week 0 and then $40 \mathrm{mg}$ every 2 weeks as subcutaneous injections), another anti-TNF- $\alpha$ antibody, for 10 weeks to patients with $\mathrm{CD}$ significantly decreased mucosal mRNA level of TNF- $\alpha$, INF- $\gamma$, IL-17A and IL-23 (Rismo et al. 2012). The decreased level of IFN- $\gamma$ may result from its reduced secretion by $\mathrm{T}$ cells and depletion of TNF levels (Agnholt and Kaltoft 2001). Decreased cytokines concentration can directly influence ROS/RNS production by inflammatory cells or indirectly modulate ROS-stimulated signalling pathways activity. However, further studies indicating the role of anti-TNF- $\alpha$ antibodies drugs on ROS/RNS production in IBD are necessary.

\section{Thiopurines}

The thiopurines, which include azathioprine (AZA) and mercaptopurine (MP), remain a mainstay in the management of IBD. Thiopurines are relatively efficacious - nearly $70 \%$ of patients with steroid-dependent IBD achieve and maintain remission (Pearson et al. 1995). However, their use is limited because of their high intolerance level and the risk of adverse reaction, which is between 15 and $28 \%$ (D'Haens et al. 1999). When metabolised, AZA is converted to 6-thioguanine nucleotides (6-TG), which is incorporated into cellular DNA and may be accumulated therein. It was shown that IBD patients have detectable 6-TG DNA in lymphocytes (Cuffari et al. 1996). It was recently described that 6-TG DNA, produced in patients under AZA treatment, increases DNA susceptibility to ROS produced in a biological context (Daehn and Karran 2009). Moreover, in the same study, the authors demonstrated that macrophages which contain DNA 6-TG are at risk from self-inflicted DNA 6-TG oxidation and their sustained high level of endogenous ROS swiftly leads to cell death.

Nevertheless, AZA remains one of the most efficient antiinflammatory drugs that decreases infiltration of inflammatory cells into the ileal mucosa in CD patients and facilitates mucosal healing (D'Haens et al. 1999).

\section{Future therapies based on anti-oxidative and anti-inflammatory drugs-brief review of experimental data}

The severity of colitis can be modified therapeutically by drugs that influence free radicals generation, neutrophil infiltration and pro-inflammatory agents' production. Uraz et al. (2013) showed that oral administration of NADPH oxidase inhibitor, NAC, to mice with acetic acid-caused UC significantly decreased pro-inflammatory cytokine concentration and lipid peroxidation, as well as elevated GSH and SOD content (Table 2). Similar results were obtained in rat model of acetic acid-induced colonic inflammation (Nosal'ova et al. 2000; Cetinkaya et al. 2005). Moreover, NAC amplified protective effect of a well-established anti-inflammatory agent, 5ASA, used in UC patients, and decreased COX-2 gene expression and prostaglandin E2 level, therefore influencing colon nitrate generation and iNOS activity (Ancha et al. 2009). NAC alone reduced iNOS level in ulcerative distal colon (Seril et al. 2002).

Romagnoli et al. (2012) reported that NAC prevents TNF- $\alpha$-induced GSH/GSSG ratio depletion in intestinal subepithelial myofibroblasts isolated from patients with active CD. The improvement of cell redox status negatively correlated with secreted matrix metalloproteinase-2, a compound responsible for a dysfunction of epithelial barrier in $\mathrm{CD}$ patients.

Recently, another natural anti-oxidant, lipoic acid, was shown to decrease tissue lipid peroxidation, MPO activity and increase GSH content in rats with ileitis or colitis (Kolgazi et al. 2007). Similarly, curcumin, an active ingredient of an Indian spice, and ellagic acid, a natural polyphenol, were used in IBD treatment for their scavenging activity to free radicals, inhibition of MPO, COX-1, COX-2, LOX, TNF- $\alpha$, IFN- $\gamma$, iNOS and positive influence on multiple signalling pathways, especially the MAPK and NF-kB [see review of Rosillo et al. (2011) and Baliga et al. (2012)].

Bjorndal et al. (2013) observed that fatty acid analogue tetradecylthioacetic acid, an anti-inflammatory and antioxidant agent, reduced colonic oxidative damage by decreasing iNOS, TNF- $\alpha$ and IL- 6 at mRNA level. Other therapeutics like tributyrin reduced mucosal damage and neutrophil and eosinophil mucosal infiltration, which was associated with a higher percentage of regulatory $\mathrm{T}$ cells and higher levels of TGF- $\beta$ and IL-10 in the lamina propria (Leonel et al. 2012). 
Table 2 Anti-oxidative and anti-inflammatory effects of therapeutics used in ulcerative colitis treatment

\begin{tabular}{|c|c|}
\hline $\begin{array}{l}\text { Antioxidants and anti-inflammatory Role } \\
\text { drugs in the treatment of IBD }\end{array}$ & $\begin{array}{l}\text { Reaction Reference } \\
\text { No. in } \\
\text { Fig. } 1\end{array}$ \\
\hline
\end{tabular}

\begin{tabular}{|c|c|c|c|}
\hline & Pre-clinical studies & & \\
\hline N-acetylocysteine & $\begin{array}{l}\downarrow \mathrm{MPO}, \uparrow \mathrm{GSH} \text { in colon lesions } \\
\downarrow \text { iNOS in distal colon lesions } \\
\downarrow \mathrm{MPO}, \uparrow \mathrm{GSH}, \mathrm{SOD}, \leftrightarrow \text { CAT in colon lesions } \\
\downarrow \mathrm{COX}-2, \text { PGE } 2, \text { nitrate concentration } \\
\downarrow \text { lipid peroxidation, } \uparrow \mathrm{GSH}, \text { SOD in ulcerative colitis } \\
\downarrow \text { COX-2 and iNOS mRNA in colon lesions } \\
\downarrow \text { iNOS activity in UC } \\
\uparrow \mathrm{GSH} / \mathrm{GSSG} \text { ratio in intestinal subepithelial } \\
\quad \text { myofibroblasts in CD }\end{array}$ & $(5)$ & $\begin{array}{l}\text { (Nosal'ova et al. 2000) } \\
\text { (Seril et al. 2002), (Cetinkaya et al. 2005) } \\
\text { (Ancha et al. 2009) } \\
\text { (Uraz et al. 2013), (Nosal'ova et al. 2000), } \\
\quad \text { (Cetinkaya et al. 2005) } \\
\text { (Ancha et al. 2009) } \\
\text { (Seril et al. 2002), (Romagnoli et al. 2012) }\end{array}$ \\
\hline Lipoic acid & $\uparrow \mathrm{GSH}, \downarrow \mathrm{MPO}$ and lipid peroxidation in ileum and colon & $(5)$ & (Kolgazi et al. 2007) \\
\hline Curcumin and ellagic acid & $\begin{array}{l}\downarrow \mathrm{MPO}, \mathrm{COX}-1, \mathrm{COX}-2, \mathrm{LOX}, \mathrm{TNF}-\alpha, \text { IFN- } \gamma, \text { iNOS } \\
\text { tissue level in CD }\end{array}$ & & (Baliga et al. 2012), (Rosillo et al. 2011) \\
\hline Tetradecylthioacetic acid & $\downarrow$ iNOS, TNF- $\alpha$ and IL-6 mRNA in ulcerative colitis & & (Bjorndal et al. 2013) \\
\hline Tributyrin & $\uparrow$ TGF- $\beta$ and IL-10 in lamina propria & & (Leonel et al. 2012) \\
\hline $\begin{array}{l}\text { Lactulose, a molecular hydrogen } \\
\text { inducer }\end{array}$ & $\begin{array}{l}\downarrow \mathrm{TNF}-\alpha, \mathrm{IL}-1 \beta, \mathrm{MPO} \text { in colon lesions } \\
\downarrow \mathrm{ONOO}-\mathrm{OH} \bullet \text { in colonic lesions }\end{array}$ & (3) & $\begin{array}{l}\text { (Chen et al. 2013) } \\
\text { (Ohsawa et al. 2007) }\end{array}$ \\
\hline Ectoine & $\begin{array}{l}\downarrow \mathrm{IL}-1 \alpha, \mathrm{IL}-6, \mathrm{IL}-8 \text { and TNF- } \alpha \\
\text { Clinical studies }\end{array}$ & & (Sydlik et al. 2009; Abdel-Aziz et al. 2013) \\
\hline Mesalazine & $\begin{array}{l}\downarrow \mathrm{O} 2 \bullet^{-}, \mathrm{H} 2 \mathrm{O} 2 \text { in UC } \\
\downarrow \text { IL-6, Il-8, } \leftrightarrow \mathrm{GSH}, \mathrm{TNF}-\alpha \text { in UC } \\
\uparrow \mathrm{TNF}-\alpha, \mathrm{IL}-1 \beta \text { and IL-6 in mucus of CD }\end{array}$ & (7) & $\begin{array}{l}\text { (Campregher et al. 2010) } \\
\text { (Guijarro et al. 2008) } \\
\text { (Yamamoto et al. 2009) }\end{array}$ \\
\hline Sulfasalazine & $\begin{array}{l}\downarrow \text { ROS } \\
\downarrow \text { IL- } 1 \beta \text { and IL- } 8 \text { mRNA }\end{array}$ & & $\begin{array}{l}\text { (Guo et al. 2011) } \\
\text { (Gan et al. 2005) }\end{array}$ \\
\hline Glucocorticoids & $\downarrow$ MPO and neutrophil elastase in paediatric IBD & & (Makitalo et al. 2012) \\
\hline Cyclosporine & $\downarrow \mathrm{IL}-2, \mathrm{IL}-3$ & & (Kountouras et al. 2004) \\
\hline Infliximab & $\begin{array}{l}\downarrow \mathrm{TNF}-\alpha \text { in colonic mucosa } \\
\downarrow \mathrm{INF}-\gamma \text { mRNA in inflammatory cells in colitis }\end{array}$ & & $\begin{array}{l}\text { (Fratila and Craciun 2010) } \\
\text { (Olsen et al. 2009) }\end{array}$ \\
\hline Adalimumab & $\begin{array}{l}\downarrow \text { TNF- } \alpha, \text { INF- } \gamma, \text { IL-17A, IL-23 mRNA in colonic } \\
\quad \text { mucosa of CD patients }\end{array}$ & & (Rismo et al. 2012) \\
\hline
\end{tabular}

$C A T$ catalase, $C D$ Crohn's disease, $G R d$ glutathione reductase, $G S H$ reduced glutathione, $G S S G$ oxidised glutathione, $G P x$ glutathione peroxidase, $\mathrm{H}_{2} \mathrm{O}_{2}$ hydrogen peroxide, $I B D$ inflammatory bowel disease, $I L$ interleukin, $I F N-\gamma$ interferon gamma, $L O X$ lipooxygenase, $M P O$ mieloperoxidase, $N O^{\circ}$ nitric oxide, $i N O S$ inducible nitric oxide synthase, $N O X$ NADPH oxidase, $O N O O^{-}$peroxynitrate, $\mathrm{O}_{2}{ }^{-}$superoxide anion, $\mathrm{OH}^{\circ}$ hydroxyl radical, $P G E_{2}$ prostaglandin $\mathrm{E}_{2}$, SOD1 copper/zinc superoxide dismutase, SOD2 mitochondrial superoxide dismutase, SOD3 extracellular superoxide dismutase, $T N F-\alpha$ tumour necrosis factor alpha, $U C$ ulcerative colitis, $X O$ xanthine oxidase

Inhibition of TNF- $\alpha$ and IL-1 $\beta$ during experimentally induced colitis can also be observed after oral administration of molecular hydrogen $\left(\mathrm{H}_{2}\right)$ inducers, like lactulose (Chen et al. 2013). The protective role of molecular hydrogen against oxidative stress is associated with $\mathrm{H}_{2}$ ability to neutralise the $\mathrm{ONOO}^{-}$and $\mathrm{OH}^{-}$(Ohsawa et al. 2007).

A natural compound ectoine found in several species of bacteria inhibits colitis by blocking nuclear translocation of NF-kB and MAPK and down-regulation of the expression of the pro-inflammatory cytokines like IL- $1 \alpha$, IL- 6 , IL-8 and TNF- $\alpha$ (Sydlik et al. 2009; Abdel-Aziz et al. 2013). Similar results were documented for parthenolide, an herbal compound, which reduced the production of TNF- $\alpha$ and IL-1 $\beta$ via influencing phosphorylation and subsequent degradation of NF-kB inhibitory protein IkB $\alpha$ in mice (Zhao et al. 2012).
As NF-kB is an oxidative stress-activated pathway, its inhibition may decrease ROS production. The activity of NF-kB pathway may also be influenced by compounds that constitute an energy source for colonic epithelial cells, like butyrate. It was indicated that in colonic epithelial cells and mucosal biopsies of CD patients, butyrate lowered LPS-induced ROS concentration and downregulated gene expression and protein content of NF-kB, TNF- $\alpha$, COX-2 and ICAM-1 (Russo et al. 2012). In addition, the inhibition of NF-kB activation affects cell apoptosis by silencing of mRNA expressions of Fas/ FasL, Bax and caspase-3, and activated $\mathrm{Bcl}-2$ genes in intestinal epithelial cells (Liu and Wang 2011). The inhibition of apoptosis prevents excessive loss of epithelial cells and therefore, intestinal injury. 
Treatment of UC can also target promoter regions for chemoprotective genes, like heme oxygenase-1 (HO-1). Recently, Yukitake et al. (2011) reported that activation of AREmediated gene expression with BTZO-15 reduced the ulcerated area by increasing expression of HO-1, suppressing NOinduced cell death and ameliorating rectal metalloproteinase activity. BTZO-15 is a derivative of BTZO-1 (BTZO-1, 2pyridin-2-yl-4H-1,3-benzothiazin-4-one) that possesses cytoprotective effect by elective bounding to macrophage migration inhibitory factor (MIF), and increasing in GSH transferase mRNA expression (Kimura et al. 2010).

Recently, Biagioni et al. (2006) reported that defective neutrophil function in patients with $\mathrm{CD}$ can be restored by granulocyte-macrophage colony-stimulating factor (GMCSF), which activates respiratory burst and improves cell viability. GM-CSF is necessary for proper mucosal barrier function, and patients with elevated GM-CSF antibody exhibit an increase in bowel permeability and disease severity vs. patients with CD with lower levels of GM-CSF antibody (Nylund et al. 2011).

\section{Conclusion}

The results of both clinical and experimental studies suggest a potential involvement of ROS and RNS in the pathomechanism of IBD and colitis-associated colorectal cancer. However, it remains unclear whether the increased oxidative stress in the gut environment results from failing metabolism, especially in mitochondria or is a reason of decreased local scavenging capacity. Also, an excessive activation of macrophage, PMN infiltration and/or activation can contribute or cause local increase in free radicals production. Probably all above-mentioned mechanisms of excessive free radicals production are engaged in the aetiology and/or exacerbation of IBD and colitis-associated colorectal cancer. Therefore, further analyses are necessary to accumulate a larger amount of data on the anti-oxidative and anti-inflammatory role of currently used therapeutics and their interference with ROS/ RNS-stimulated signalling pathways.

Clinical studies with existing and potential anti-IBD drugs, especially those employing natural antioxidants show promising outcomes for IBD and colorectal cancer treatment (Rosillo et al. 2011; Baliga et al. 2012). However, since numerous intestinal factors like bacteria, digestive enzymes or food metabolites can change the anti-oxidative properties of drugs potentially inactive, further clinical trials are necessary. The knowledge on highly specific anti-oxidative effects of currently used therapeutics and novel agents may provide significant clinical benefits in the treatment and relapse of IBD.

It is likely that, in the near future, combination of currently used pharmaceutics with natural and synthetic potent anti- oxidative compounds, like lipoic acid or curcumine, will become a strategy of choice in IBD treatment.

Acknowledgments This study was supported by the Iuventus Plus programme of the Polish Ministry of Science and Higher Education (0119/IP1/2011/71 and IP2012 010772 to JF).

Open Access This article is distributed under the terms of the Creative Commons Attribution License which permits any use, distribution, and reproduction in any medium, provided the original author(s) and the source are credited.

\section{References}

Abdel-Aziz H, Wadie W, Abdallah DM, Lentzen G, Khayyal MT (2013) Novel effects of ectoine, a bacteria-derived natural tetrahydropyrimidine, in experimental colitis. Phytomedicine : international journal of phytotherapy and phytopharmacology

Agnholt J, Kaltoft K (2001) Infliximab downregulates interferon-gamma production in activated gut T-lymphocytes from patients with Crohn's disease. Cytokine 15:212-222

Ancha HR, Kurella RR, McKimmey CC, Lightfoot S, Harty RF (2009) Effects of $\mathrm{N}$-acetylcysteine plus mesalamine on prostaglandin synthesis and nitric oxide generation in TNBS-induced colitis in rats. Dig Dis Sci 54:758-766

Ardite E, Panes J, Miranda M, Salas A, Elizalde JI, Sans M, Arce Y, Bordas JM, Fernandez-Checa JC, Pique JM (1998) Effects of steroid treatment on activation of nuclear factor kappaB in patients with inflammatory bowel disease. Br J Pharmacol 124:431-433

Arijs I, De Hertogh G, Machiels K, Van Steen K, Lemaire K, Schraenen A, Van Lommel L, Quintens R, Van Assche G, Vermeire S, Schuit F, Rutgeerts P (2011) Mucosal gene expression of cell adhesion molecules, chemokines, and chemokine receptors in patients with inflammatory bowel disease before and after infliximab treatment. Am J Gastroenterol 106:748-761

Aw TY (2005) Intestinal glutathione: determinant of mucosal peroxide transport, metabolism, and oxidative susceptibility. Toxicol Appl Pharmacol 204:320-328

Bachhawat AK, Thakur A, Kaur J, Zulkifli M (2013) Glutathione transporters. Biochim Biophys Acta 1830:3154-3164

Baert FJ, D'Haens GR, Peeters M, Hiele MI, Schaible TF, Shealy D, Geboes K, Rutgeerts PJ (1999) Tumor necrosis factor alpha antibody (infliximab) therapy profoundly down-regulates the inflammation in Crohn's ileocolitis. Gastroenterology 116:22-28

Baliga MS, Joseph N, Venkataranganna MV, Saxena A, Ponemone V, Fayad R (2012) Curcumin, an active component of turmeric in the prevention and treatment of ulcerative colitis: preclinical and clinical observations. Food funct 3:1109-1117

Bantel H, Schmitz ML, Raible A, Gregor M, Schulze-Osthoff K (2002) Critical role of NF-kappaB and stress-activated protein kinases in steroid unresponsiveness. FASEB J official Publ Fed Am Soc Exp Biol 16:1832-1834

Bao Y, Jemth P, Mannervik B, Williamson G (1997) Reduction of thymine hydroperoxide by phospholipid hydroperoxide glutathione peroxidase and glutathione transferases. FEBS Lett 410:210-212

Bao S, Carr ED, Xu YH, Hunt NH (2011) Gp91 (phox) contributes to the development of experimental inflammatory bowel disease. Immunol Cell Biol 89:853-860

Beltran B, Nos P, Dasi F, Iborra M, Bastida G, Martinez M, O'Connor JE, Saez G, Moret I, Ponce J (2010) Mitochondrial dysfunction, persistent oxidative damage, and catalase inhibition in immune cells of naive and treated Crohn's disease. Inflamm Bowel Dis 16:76-86 
Biagioni C, Favilli F, Catarzi S, Marcucci T, Fazi M, Tonelli F, Vincenzini MT, Iantomasi T (2006) Redox state and O2*-production in neutrophils of Crohn's disease patients. Exp Biol Med 231:186-195

Binion DG, Rafiee P, Ramanujam KS, Fu S, Fisher PJ, Rivera MT, Johnson CP, Otterson MF, Telford GL, Wilson KT (2000) Deficient iNOS in inflammatory bowel disease intestinal microvascular endothelial cells results in increased leukocyte adhesion. Free Radic Biol Med 29:881-888

Bjorndal B, Grimstad T, Cacabelos D, Nylund K, Aasprong OG, Omdal R, Portero-Otin M, Pamplona R, Lied GA, Hausken T, Berge RK (2013) Tetradecylthioacetic acid attenuates inflammation and has antioxidative potential during experimental colitis in rats. Dig Dis Sci 58:97-106

Boehm D, Krzystek-Korpacka M, Neubauer K, Matusiewicz M, Paradowski L, Gamian A (2012) Lipid peroxidation markers in Crohn's disease: the associations and diagnostic value. Clin Chem Lab Med CCLM/FESCC 50:1359-1366

Boschetti G, Nancey S, Sardi F, Roblin X, Flourie B, Kaiserlian D (2011) Therapy with anti-TNFalpha antibody enhances number and function of Foxp3 $(+)$ regulatory T cells in inflammatory bowel diseases. Inflamm Bowel Dis 17:160-170

Brennan FM, Maini RN, Feldmann M (1995) Cytokine expression in chronic inflammatory disease. Br Med Bull 51:368-384

Brindley DN, Abousalham A, Kikuchi Y, Wang CN, Waggoner DW (1996) "Cross talk" between the bioactive glycerolipids and sphingolipids in signal transduction. biochemistry and cell biology. Biochim Biol Cell 74:469-476

Campregher C, Luciani MG, Biesenbach P, Evstatiev R, Lyakhovich A, Gasche $C$ (2010) The position of the amino group on the benzene ring is critical for mesalamine's improvement of replication fidelity. Inflamm Bowel Dis 16:576-582

Catala A (2009) Lipid peroxidation of membrane phospholipids generates hydroxy-alkenals and oxidized phospholipids active in physiological and/or pathological conditions. Chem Phys Lipids 157:1-11

Cetinkaya A, Bulbuloglu E, Kurutas EB, Ciralik H, Kantarceken B, Buyukbese MA (2005) Beneficial effects of N-acetylcysteine on acetic acid-induced colitis in rats. Tohoku J Exp Med 206:131-139

Chang LC, Fan CW, Tseng WK, Chen JR, Chein HP, Hwang CC, Hua CC (2013) Immunohistochemical study of the Nrf2 pathway in colorectal cancer: $\mathrm{Nrf} 2$ expression is closely correlated to Keap1 in the tumor and Bach1 in the normal tissue. Applied immunohistochemistry \& molecular morphology : AIMM / official publication of the Society for Applied Immunohistochemistry

Chawla N, Butler EN, Lund J, Warren JL, Harlan LC, Yabroff KR (2013) Patterns of colorectal cancer care in Europe, Australia, and New Zealand. J Natl Cancer Inst Monogr 2013:36-61

Chen QK, Yuan SZ, Wen ZF, Zhong YQ, Li CJ, Wu HS, Mai CR, Xie PY, $\mathrm{Lu}$ YM, Yu ZL (2005) Characteristics and therapeutic efficacy of sulfasalazine in patients with mildly and moderately active ulcerative colitis. World J Gastroenterol:WJG 11:2462-2466

Chen X, Zhai X, Shi J, Liu WW, Tao H, Sun X, Kang Z (2013) Lactulose mediates suppression of dextran sodium sulfate-induced colon inflammation by increasing hydrogen production. Digestive diseases and sciences

Cuffari C, Seidman EG, Latour S, Theoret Y (1996) Quantitation of 6thioguanine in peripheral blood leukocyte DNA in Crohn's disease patients on maintenance 6-mercaptopurine therapy. Can J Physiol Pharmacol 74:580-585

Curran FT, Allan RN, Keighley MR (1991) Superoxide production by Crohn's disease neutrophils. Gut 32:399-402

Daehn I, Karran P (2009) Immune effector cells produce lethal DNA damage in cells treated with a thiopurine. Cancer Res 69:2393-2399

Davis RJ (2000) Signal transduction by the JNK group of MAP kinases. Cell 103:239-252

de Mochel NS, Seronello S, Wang SH, Ito C, Zheng JX, Liang TJ, Lambeth JD, Choi J (2010) Hepatocyte NAD (P) H oxidases as an endogenous source of reactive oxygen species during hepatitis $\mathrm{C}$ virus infection. Hepatology 52:47-59

D'Haens G, Geboes K, Rutgeerts P (1999) Endoscopic and histologic healing of Crohn's (ileo-) colitis with azathioprine. Gastrointest Endosc 50:667-671

Dijkstra G, Moshage H, van Dullemen HM, de Jager-Krikken A, Tiebosch AT, Kleibeuker JH, Jansen PL, van Goor H (1998) Expression of nitric oxide synthases and formation of nitrotyrosine and reactive oxygen species in inflammatory bowel disease. J Pathol 186:416-421

Dutta S, Rittinger K (2010) Regulation of NOXO1 activity through reversible interactions with $\mathrm{p} 22$ and NOXA1. PLoS One 5:e10478

Ebert EC, Mehta V, Das KM (2005) Activation antigens on colonic T cells in inflammatory bowel disease: effects of IL-10. Clin Exp Immunol 140:157-165

Egan LJ, Sandborn WJ, Tremaine WJ (1998) Clinical outcome following treatment of refractory inflammatory and fistulizing Crohn's disease with intravenous cyclosporine. Am J Gastroenterol 93:442-448

Esworthy RS, Swiderek KM, Ho YS, Chu FF (1998) Seleniumdependent glutathione peroxidase-GI is a major glutathione peroxidase activity in the mucosal epithelium of rodent intestine. Biochim Biophys Acta 1381:213-226

Florian S, Krehl S, Loewinger M, Kipp A, Banning A, Esworthy S, Chu FF, Brigelius-Flohe R (2010) Loss of GPx2 increases apoptosis, mitosis, and GPx1 expression in the intestine of mice. Free Radic Biol Med 49:1694-1702

Fransen M, Nordgren M, Wang B, Apanasets O (2012) Role of peroxisomes in ROS/RNS-metabolism: implications for human disease. Biochim Biophys Acta 1822:1363-1373

Fratila OC, Craciun C (2010) Ultrastructural evidence of mucosal healing after infliximab in patients with ulcerative colitis. J Gastrointest Liver Dis:JGLD 19:147-153

Fridovich I (1997) Superoxide anion radical $\left(\mathrm{O}_{2-}^{-}\right)$, superoxide dismutases, and related matters. J Biol Chem 272:18515-18517

Gan HT, Chen YQ, Ouyang Q (2005) Sulfasalazine inhibits activation of nuclear factor-kappaB in patients with ulcerative colitis. J Gastroenterol Hepatol 20:1016-1024

Geiszt M, Lekstrom K, Brenner S, Hewitt SM, Dana R, Malech HL, Leto TL (2003) NAD (P) H oxidase 1, a product of differentiated colon epithelial cells, can partially replace glycoprotein 91phox in the regulated production of superoxide by phagocytes. J Immunol 171:299-306

Ghafourifar P, Cadenas E (2005) Mitochondrial nitric oxide synthase. Trends Pharmacol Sci 26:190-195

Graham PM, Li JZ, Dou X, Zhu H, Misra HP, Jia Z, Li Y (2013) Protection against peroxynitrite-induced DNA damage by mesalamine: implications for anti-inflammation and anti-cancer activity. Mol Cell Biochem 378:291-298

Guijarro LG, Mate J, Gisbert JP, Perez-Calle JL, Marin-Jimenez I, Arriaza E, Olleros T, Delgado M, Castillejo MS, Prieto-Merino D, Gonzalez Lara V, Pena AS (2008) N-acetyl-L-cysteine combined with mesalamine in the treatment of ulcerative colitis: randomized, placebo-controlled pilot study. World J Gastroenterol:WJG 14: 2851-2857

Guo W, Zhao Y, Zhang Z, Tan N, Zhao F, Ge C, Liang L, Jia D, Chen T, Yao M, Li J, He X (2011) Disruption of xCT inhibits cell growth via the ROS/autophagy pathway in hepatocellular carcinoma. Cancer Lett 312:55-61

Halliwell B (1999) Oxygen and nitrogen are pro-carcinogens. Damage to DNA by reactive oxygen, chlorine and nitrogen species: measurement, mechanism and the effects of nutrition. Mutat Res 443:37-52

Hart AL, Ng SC (2010) Review article: the optimal medical management of acute severe ulcerative colitis. Aliment Pharmacol Ther 32:615627

Hsu WH, Hsieh YS, Kuo HC, Teng CY, Huang HI, Wang CJ, Yang SF, Liou YS, Kuo WH (2007) Berberine induces apoptosis in SW620 
human colonic carcinoma cells through generation of reactive oxygen species and activation of JNK/p38 MAPK and FasL. Arch Toxicol 81:719-728

Ina K, Kusugami K, Shimada M, Tsuzuki T, Nishio Y, Binion DG, Imada A, Ando T (2002) Suppressive effects of cyclosporine A on neutrophils and $\mathrm{T}$ cells may be related to therapeutic benefits in patients with steroid-resistant ulcerative colitis. Inflamm Bowel Dis 8:1-9

Ischiropoulos H, Al-Mehdi AB (1995) Peroxynitrite-mediated oxidative protein modifications. FEBS Lett 364:279-282

Iwata S, Hori T, Sato N, Hirota K, Sasada T, Mitsui A, Hirakawa T, Yodoi J (1997) Adult T cell leukemia (ATL)-derived factor/human thioredoxin prevents apoptosis of lymphoid cells induced by Lcystine and glutathione depletion: possible involvement of thiolmediated redox regulation in apoptosis caused by pro-oxidant state. J Immunol 158:3108-3117

Khodayari S, Salehi Z, Fakhrieh Asl S, Aminian K, Mirzaei Gisomi N, Torabi Dalivandan S (2013) Catalase gene C-262T polymorphism: importance in ulcerative colitis. Journal of gastroenterology and hepatology

Kim H, Kim KH (1998) Effect of nitric oxide on hydrogen peroxideinduced damage in isolated rabbit gastric glands. Pharmacology 57: 323-330

Kim M, Lee S, Yang SK, Song K, Lee I (2006) Differential expression in histologically normal crypts of ulcerative colitis suggests primary crypt disorder. Oncol Rep 16:663-670

Kim JY, Cho HJ, Sir JJ, Kim BK, Hur J, Youn SW, Yang HM, Jun SI, Park KW, Hwang SJ, Kwon YW, Lee HY, Kang HJ, Oh BH, Park YB, Kim HS (2009) Sulfasalazine induces haem oxygenase-1 via ROS-dependent Nrf2 signalling, leading to control of neointimal hyperplasia. Cardiovasc Res 82:550-560

Kimura I, Kawasaki M, Matsuda A, Kataoka M, Kokurba Y (1998) Effects of BX661A, a new therapeutic agent for ulcerative colitis, on chemotaxis and reactive oxygen species production in polymorphonuclear leukocytes in comparison with salazosulfapyridine and its metabolite sulfapyridine. Arzneimittelforschung 48:1163-1167

Kimura H, Sato Y, Tajima Y, Suzuki H, Yukitake H, Imaeda T, Kajino M, Oki H, Takizawa M, Tanida S (2010) BTZO-1, a cardioprotective agent, reveals that macrophage migration inhibitory factor regulates ARE-mediated gene expression. Chem Biol 17:1282-1294

King N, Lin H, Suleiman MS (2011) Oxidative stress increases SNAT1 expression and stimulates cysteine uptake in freshly isolated rat cardiomyocytes. Amino Acids 40:517-526

Kolgazi M, Jahovic N, Yuksel M, Ercan F, Alican I (2007) Alpha-lipoic acid modulates gut inflammation induced by trinitrobenzene sulfonic acid in rats. J Gastroenterol Hepatol 22:1859-1865

Kountouras J, Zavos C, Chatzopoulos D (2004) Immunomodulatory benefits of cyclosporine a in inflammatory bowel disease. J Cell Mol Med 8:317-328

Krieglstein CF, Cerwinka WH, Laroux FS, Salter JW, Russell JM, Schuermann G, Grisham MB, Ross CR, Granger DN (2001) Regulation of murine intestinal inflammation by reactive metabolites of oxygen and nitrogen: divergent roles of superoxide and nitric oxide. J Exp Med 194:1207-1218

Kruidenier L, Verspaget HW (2002) Review article: oxidative stress as a pathogenic factor in inflammatory bowel disease - radicals or ridiculous? Aliment Pharmacol Ther 16:1997-2015

Kruidenier L, Kuiper I, Lamers CB, Verspaget HW (2003) Intestinal oxidative damage in inflammatory bowel disease: semiquantification, localization, and association with mucosal antioxidants. J Pathol 201:28-36

Kuhn H, Borchert A (2002) Regulation of enzymatic lipid peroxidation: the interplay of peroxidizing and peroxide reducing enzymes. Free Radic Biol Med 33:154-172

Leonard N, Bishop AE, Polak JM, Talbot IC (1998) Expression of nitric oxide synthase in inflammatory bowel disease is not affected by corticosteroid treatment. J Clin Pathol 51:750-753
Leonel AJ, Teixeira LG, Oliveira RP, Santiago AF, Batista NV, Ferreira TR, Santos RC, Cardoso VN, Cara DC, Faria AM, Alvarez-Leite J (2012) Antioxidative and immunomodulatory effects of tributyrin supplementation on experimental colitis. Br J Nutr 1-12

Li Y, Huang TT, Carlson EJ, Melov S, Ursell PC, Olson JL, Noble LJ, Yoshimura MP, Berger C, Chan PH, Wallace DC, Epstein CJ (1995) Dilated cardiomyopathy and neonatal lethality in mutant mice lacking manganese superoxide dismutase. Nat Genet 11:376-381

Li Z, Arijs I, De Hertogh G, Vermeire S, Noman M, Bullens D, Coorevits L, Sagaert X, Schuit F, Rutgeerts P, Ceuppens JL, Van Assche G (2010) Reciprocal changes of Foxp3 expression in blood and intestinal mucosa in IBD patients responding to infliximab. Inflamm Bowel Dis 16:1299-1310

Liptay S, Bachem M, Hacker G, Adler G, Debatin KM, Schmid RM (1999) Inhibition of nuclear factor kappa B and induction of apoptosis in T-lymphocytes by sulfasalazine. Br J Pharmacol 128:13611369

Liu X, Wang JM (2011) Iridoid glycosides fraction of Folium syringae leaves modulates NF-kappaB signal pathway and intestinal epithelial cells apoptosis in experimental colitis. PLoS One 6:e24740

Ljung T, Lundberg S, Varsanyi M, Johansson C, Schmidt PT, Herulf M, Lundberg JO, Hellstrom PM (2006) Rectal nitric oxide as biomarker in the treatment of inflammatory bowel disease: responders versus nonresponders. World J Gastroenterol:WJG 12:3386-3392

Makitalo L, Rintamaki H, Tervahartiala T, Sorsa T, Kolho KL (2012) Serum MMPs 7-9 and their inhibitors during glucocorticoid and anti-TNF-alpha therapy in pediatric inflammatory bowel disease. Scand J Gastroenterol 47:785-794

Maor I, Rainis T, Lanir A, Lavy A (2008) Oxidative stress, inflammation and neutrophil superoxide release in patients with Crohn's disease: distinction between active and non-active disease. Dig Dis Sci 53: $2208-2214$

Marklund SL (1982) Human copper-containing superoxide dismutase of high molecular weight. Proc Natl Acad Sci U S A 79:7634-7638

Masuda H, Takahashi Y, Nishida Y, Asai S (2012) Comparison of the effect of mesalazine and sulfasalazine on laboratory parameters: a retrospective observational study. Eur J Clin Pharmacol 68:15491555

Matheson PJ, Wilson MA, Garrison RN (2000) Regulation of intestinal blood flow. J Surg Res 93:182-196

Miller DM, Buettner GR, Aust SD (1990) Transition metals as catalysts of "autoxidation" reactions. Free Radic Biol Med 8:95-108

Miralles-Barrachina O, Savoye G, Belmonte-Zalar L, Hochain P, Ducrotte P, Hecketsweiler B, Lerebours E, Dechelotte P (1999) Low levels of glutathione in endoscopic biopsies of patients with Crohn's colitis: the role of malnutrition. Clin Nutr 18:313-317

Muller FL, Liu Y, Van Remmen H (2004) Complex III releases superoxide to both sides of the inner mitochondrial membrane. J Biol Chem 279:49064-49073

Nielsen OH, Koppen T, Rudiger N, Horn T, Eriksen J, Kirman I (1996) Involvement of interleukin-4 and -10 in inflammatory bowel disease. Dig Dis Sci 41:1786-1793

Nosal'ova V, Cerna S, Bauer V (2000) Effect of N-acetylcysteine on colitis induced by acetic acid in rats. Gen Pharmacol 35:77-81

Nylund CM, D'Mello S, Kim MO, Bonkowski E, Dabritz J, Foell D, Meddings J, Trapnell BC, Denson LA (2011) Granulocyte macrophage-colony-stimulating factor autoantibodies and increased intestinal permeability in Crohn disease. J Pediatr Gastroenterol Nutr 52:542-548

Ohsawa I, Ishikawa M, Takahashi K, Watanabe M, Nishimaki K, Yamagata K, Katsura K, Katayama Y, Asoh S, Ohta S (2007) Hydrogen acts as a therapeutic antioxidant by selectively reducing cytotoxic oxygen radicals. Nat Med 13:688-694

Olsen T, Cui G, Goll R, Husebekk A, Florholmen J (2009) Infliximab therapy decreases the levels of TNF-alpha and IFN-gamma mRNA 
in colonic mucosa of ulcerative colitis. Scand J Gastroenterol 44: $727-735$

Ono K, Han J (2000) The p38 signal transduction pathway: activation and function. Cell Signal 12:1-13

Park EJ, Lim JH, Nam SI, Park JW, Kwon TK (2010) Rottlerin induces heme oxygenase-1 (HO-1) up-regulation through reactive oxygen species (ROS) dependent and PKC delta-independent pathway in human colon cancer HT29 cells. Biochimie 92:110-115

Pearson DC, May GR, Fick GH, Sutherland LR (1995) Azathioprine and 6-mercaptopurine in Crohn disease. A meta-analysis. Ann Intern Med 123:132-142

Perner A, Andresen L, Normark M, Fischer-Hansen B, Sorensen S, Eugen-Olsen J, Rask-Madsen J (2001) Expression of nitric oxide synthases and effects of L-arginine and L-NMMA on nitric oxide production and fluid transport in collagenous colitis. Gut 49:387-394

Pietarinen-Runtti P, Lakari E, Raivio KO, Kinnula VL (2000) Expression of antioxidant enzymes in human inflammatory cells. Am J Physiol Cell Physiol 278:C118-C125

Podolsky DK (2002) Inflammatory bowel disease. N Engl J Med 347: 417-429

Poli G, Schaur RJ, Siems WG, Leonarduzzi G (2008) 4-Hydroxynonenal: a membrane lipid oxidation product of medicinal interest. Med Res Rev 28:569-631

Poulsen NA, Andersen V, Moller JC, Moller HS, Jessen F, Purup S, Larsen LB (2012) Comparative analysis of inflamed and noninflamed colon biopsies reveals strong proteomic inflammation profile in patients with ulcerative colitis. BMC Gastroenterol 12:76

Pruzanski W, Stefanski E, Vadas P, Ramamurthy NS (1997) Inhibition of extracellular release of proinflammatory secretory phospholipase A2 (sPLA2) by sulfasalazine: a novel mechanism of antiinflammatory activity. Biochem Pharmacol 53:1901-1907

Rachmilewitz D, Stamler JS, Bachwich D, Karmeli F, Ackerman Z, Podolsky DK (1995) Enhanced colonic nitric oxide generation and nitric oxide synthase activity in ulcerative colitis and Crohn's disease. Gut 36:718-723

Raddatz D, Bockemuhl M, Ramadori G (2005) Quantitative measurement of cytokine mRNA in inflammatory bowel disease: relation to clinical and endoscopic activity and outcome. Eur J Gastroenterol Hepatol 17:547-557

Rafa H, Saoula H, Belkhelfa M, Medjeber O, Soufli I, Toumi R, de Launoit Y, Morales O, Nakmouche M, Delhem N, Touil-Boukoffa C (2013) IL-23/IL-17A axis correlates with the nitric oxide pathway in inflammatory bowel disease: immunomodulatory effect of retinoic acid. Journal of interferon \& cytokine research : the official journal of the International Society for Interferon and Cytokine Research

Rahman I, Smith CA, Antonicelli F, MacNee W (1998) Characterisation of gamma-glutamylcysteine synthetase-heavy subunit promoter: a critical role for AP-1. FEBS Lett 427:129-133

Reddy NM, Kleeberger SR, Bream JH, Fallon PG, Kensler TW, Yamamoto M, Reddy SP (2008) Genetic disruption of the Nrf2 compromises cell-cycle progression by impairing GSH-induced redox signaling. Oncogene 27:5821-5832

Ridnour LA, Isenberg JS, Espey MG, Thomas DD, Roberts DD, Wink DA (2005) Nitric oxide regulates angiogenesis through a functional switch involving thrombospondin-1. Proc Natl Acad Sci U S A 102: 13147-13152

Rijk MC, van Schaik A, van Tongeren JH (1988) Disposition of 5aminosalicylic acid by 5 -aminosalicylic acid-delivering compounds. Scand J Gastroenterol Suppl 148:54-59

Rismo R, Olsen T, Ciu G, Paulssen EJ, Christiansen I, Florholmen J, Goll $R$ (2012) The effect of adalimumab for induction of endoscopic healing and normalization of mucosal cytokine gene expression in Crohn's disease. Scand J Gastroenterol 47:1200-1210

Romagnoli C, Marcucci T, Picariello L, Tonelli F, Vincenzini MT, Iantomasi T (2012) Role of N-acetylcysteine and GSH redox system on total and active MMP-2 in intestinal myofibroblasts of Crohn's disease patients. International journal of colorectal disease

Rosillo MA, Sanchez-Hidalgo M, Cardeno A, de la Lastra CA (2011) Protective effect of ellagic acid, a natural polyphenolic compound, in a murine model of Crohn's disease. Biochem Pharmacol 82:737745

Russo I, Luciani A, De Cicco P, Troncone E, Ciacci C (2012) Butyrate attenuates lipopolysaccharide-induced inflammation in intestinal cells and Crohn's mucosa through modulation of antioxidant defense machinery. PLoS One 7:e32841

Sanders LM, Henderson CE, Hong MY, Barhoumi R, Burghardt RC, Carroll RJ, Turner ND, Chapkin RS, Lupton JR (2004) Pro-oxidant environment of the colon compared to the small intestine may contribute to greater cancer susceptibility. Cancer Lett 208:155-161

Scharlau D, Borowicki A, Habermann N, Hofmann T, Klenow S, Miene C, Munjal U, Stein K, Glei M (2009) Mechanisms of primary cancer prevention by butyrate and other products formed during gut floramediated fermentation of dietary fibre. Mutat Res 682:39-53

Scherer DC, Brockman JA, Chen Z, Maniatis T, Ballard DW (1995) Signal-induced degradation of I kappa B alpha requires site-specific ubiquitination. Proc Natl Acad Sci U S A 92:11259-11263

Schreiber S, Nikolaus S, Hampe J (1998) Activation of nuclear factor kappa B inflammatory bowel disease. Gut 42:477-484

Schuhmacher S, Oelze M, Bollmann F, Kleinert H, Otto C, Heeren T, Steven S, Hausding M, Knorr M, Pautz A, Reifenberg K, Schulz E, Gori T, Wenzel P, Munzel T, Daiber A (2011) Vascular dysfunction in experimental diabetes is improved by pentaerithrityl tetranitrate but not isosorbide-5-mononitrate therapy. Diabetes 60:2608-2616

Seiler A, Schneider M, Forster H, Roth S, Wirth EK, Culmsee C, Plesnila N, Kremmer E, Radmark O, Wurst W, Bornkamm GW, Schweizer U, Conrad M (2008) Glutathione peroxidase 4 senses and translates oxidative stress into 12/15-lipoxygenase dependent- and AIFmediated cell death. Cell Metab 8:237-248

Seril DN, Liao J, Ho KL, Yang CS, Yang GY (2002) Inhibition of chronic ulcerative colitis-associated colorectal adenocarcinoma development in a murine model by N-acetylcysteine. Carcinogenesis 23:993-1001

Seril DN, Liao J, Yang GY, Yang CS (2003) Oxidative stress and ulcerative colitis-associated carcinogenesis: studies in humans and animal models. Carcinogenesis 24:353-362

Sies H, Sharov VS, Klotz LO, Briviba K (1997) Glutathione peroxidase protects against peroxynitrite-mediated oxidations. A new function for selenoproteins as peroxynitrite reductase. J Biol Chem 272: 27812-27817

Singer II, Kawka DW, Scott S, Weidner JR, Mumford RA, Riehl TE, Stenson WF (1996) Expression of inducible nitric oxide synthase and nitrotyrosine in colonic epithelium in inflammatory bowel disease. Gastroenterology 111:871-885

Sklyarov AY, Panasyuk NB, Fomenko IS (2011) Role of nitric oxidesynthase and cyclooxygenase/lipooxygenase systems in development of experimental ulcerative colitis. Can J Physiol Pharmacol : Off J Pol Physiol Soc 62:65-73

Sun L, Wang X, Yao H, Li W, Son YO, Luo J, Liu J, Zhang Z (2012) Reactive oxygen species mediate $\mathrm{Cr}(\mathrm{VI})$-induced $\mathrm{S}$ phase arrest through p53 in human colon cancer cells. J Environ Pathol Toxicol Oncol off organ Int Soc Environ toxic Cancer 31:95-107

Sydlik U, Gallitz I, Albrecht C, Abel J, Krutmann J, Unfried K (2009) The compatible solute ectoine protects against nanoparticle-induced neutrophilic lung inflammation. Am J Respir Crit Care Med 180:29-35

Tabatabaie T, Potts JD, Floyd RA (1996) Reactive oxygen speciesmediated inactivation of pyruvate dehydrogenase. Arch Biochem Biophys 336:290-296

Takeuchi T, Nakajima M, Morimoto K (1996) Relationship between the intracellular reactive oxygen species and the induction of oxidative DNA damage in human neutrophil-like cells. Carcinogenesis 17: $1543-1548$ 
Tan S, Yokoyama Y, Dickens E, Cash TG, Freeman BA, Parks DA (1993) Xanthine oxidase activity in the circulation of rats following hemorrhagic shock. Free Radic Biol Med 15:407-414

Te Velde AA, Pronk I, de Kort F, Stokkers PC (2008) Glutathione peroxidase 2 and aquaporin 8 as new markers for colonic inflammation in experimental colitis and inflammatory bowel diseases: an important role for H2O2? Eur J Gastroenterol Hepatol 20:555-560

Tham DM, Whitin JC, Kim KK, Zhu SX, Cohen HJ (1998) Expression of extracellular glutathione peroxidase in human and mouse gastrointestinal tract. Am J Physiol 275:G1463-G1471

Tsunada S, Iwakiri R, Ootani H, Aw TY, Fujimoto K (2003) Redox imbalance in the colonic mucosa of ulcerative colitis. Scand J Gastroenterol 38:1002-1003

Tuzun A, Erdil A, Inal V, Aydin A, Bagci S, Yesilova Z, Sayal A, Karaeren N, Dagalp K (2002) Oxidative stress and antioxidant capacity in patients with inflammatory bowel disease. Clin Biochem 35:569-572

Uchiyama K, Naito Y, Takagi T, Mizushima K, Hirai Y, Hayashi N, Harusato A, Inoue K, Fukumoto K, Yamada S, Handa O, Ishikawa T, Yagi N, Kokura S, Yoshikawa T (2012) Serpin B1 protects colonic epithelial cell via blockage of neutrophil elastase activity and its expression is enhanced in patients with ulcerative colitis. Am J Physiol Gastrointest Liver Physiol 302:G1163-G1170

Uraz S, Tahan G, Aytekin H, Tahan V (2013) N-acetylcysteine expresses powerful anti-inflammatory and antioxidant activities resulting in complete improvement of acetic acid-induced colitis in rats. Scand J Clin Lab Invest 73:61-66

Valko M, Morris H, Mazur M, Rapta P, Bilton RF (2001) Oxygen free radical generating mechanisms in the colon: do the semiquinones of vitamin K play a role in the aetiology of colon cancer? Biochim Biophys Acta 1527:161-166

Valko M, Leibfritz D, Moncol J, Cronin MT, Mazur M, Telser J (2007) Free radicals and antioxidants in normal physiological functions and human disease. Int J Biochem Cell Biol 39:44-84

Verspaget HW, Mieremet-Ooms MA, Weterman IT, Pena AS (1984) Partial defect of neutrophil oxidative metabolism in Crohn's disease. Gut 25:849-853

Verspaget HW, Pena AS, Weterman IT, Lamers CB (1988) Diminished neutrophil function in Crohn's disease and ulcerative colitis identified by decreased oxidative metabolism and low superoxide dismutase content. Gut 29:223-228
Waetzig GH, Seegert D, Rosenstiel P, Nikolaus S, Schreiber S (2002) p38 mitogen-activated protein kinase is activated and linked to TNFalpha signaling in inflammatory bowel disease. J Immunol 168: $5342-5351$

Wakeman D, Guo J, Santos JA, Wandu WS, Schneider JE, McMellen ME, Leinicke JA, Erwin CR, Warner BW (2012) p38 MAPK regulates Bax activity and apoptosis in enterocytes at baseline and after intestinal resection. Am J Physiol Gastrointest Liver Physiol 302:G997-G1005

Wendland BE, Aghdassi E, Tam C, Carrrier J, Steinhart AH, Wolman SL, Baron D, Allard JP (2001) Lipid peroxidation and plasma antioxidant micronutrients in Crohn disease. Am J Clin Nutr 74:259-264

Winczura A, Zdzalik D, Tudek B (2012) Damage of DNA and proteins by major lipid peroxidation products in genome stability. Free Radic Res 46:442-459

Wu G, Knabe DA, Yan W, Flynn NE (1995) Glutamine and glucose metabolism in enterocytes of the neonatal pig. Am J Physiol 268: R334-R342

Yamamoto T, Umegae S, Matsumoto K (2009) Impact of infliximab therapy after early endoscopic recurrence following ileocolonic resection of Crohn's disease: a prospective pilot study. Inflamm Bowel Dis 15:1460-1466

Yasukawa K, Tokuda H, Tun X, Utsumi H, Yamada K (2012) The detrimental effect of nitric oxide on tissue is associated with inflammatory events in the vascular endothelium and neutrophils in mice with dextran sodium sulfate-induced colitis. Free Radic Res 46: $1427-1436$

Yuan W, Ge H, He B (2010) Pro-inflammatory activities induced by CyPA-EMMPRIN interaction in monocytes. Atherosclerosis 213: 415-421

Yukitake H, Kimura H, Suzuki H, Tajima Y, Sato Y, Imaeda T, Kajino M, Takizawa M (2011) BTZO-15, an ARE-activator, ameliorates DSSand TNBS-induced colitis in rats. PLoS One 6:e23256

Zhao ZJ, Xiang JY, Liu L, Huang XL, Gan HT (2012) Parthenolide, an inhibitor of the nuclear factor-kappaB pathway, ameliorates dextran sulfate sodium-induced colitis in mice. Int Immunopharmacol 12: 169-174

Zwolinska-Wcislo M, Brzozowski T, Ptak-Belowska A, Targosz A, Urbanczyk K, Kwiecien S, Sliwowski Z (2011) Nitric oxidereleasing aspirin but not conventional aspirin improves healing of experimental colitis. World J Gastroenterol:WJG 17:4076-4089 